\title{
Exploring drug metabolism by the gut microbiota: modes of metabolism and experimental approaches
}

Authors: Pooja Dhurjad ${ }^{1}$, Chinmayi Dhavaliker ${ }^{1}$, Kajal Gupta ${ }^{1}$, Rajesh Sonti ${ }^{1} *$

\section{Author Affiliations:}

${ }^{1}$ Department of Pharmaceutical Analysis, National Institute of Pharmaceutical Education and Research (NIPER), Hyderabad, Balanagar, Telangana, India - 500037.

\section{*Corresponding author:}

Rajesh Sonti, $\mathrm{PhD}$

Assistant Professor,

Department of Pharmaceutical Analysis,

National Institute of Pharmaceutical Education and Research (NIPER), Hyderabad, Balanagar, Telangana, India - 500037.

Phone: +91-9172273849

Email: rajesh.sonti@niperhyd.ac.in 
Running title: Drug metabolism by the gut microbiota

\section{Corresponding author:}

Rajesh Sonti, PhD

Assistant Professor,

Department of Pharmaceutical Analysis,

National Institute of Pharmaceutical Education and Research (NIPER), Hyderabad, Balanagar,

Telangana, India - 500037.

Phone: +91-9172273849

Email: rajesh.sonti@niperhyd.ac.in

Number of text pages: 57

Number of tables: 2

Number of figures: 4

Number of words in Abstract: 106

Number of words in introduction: 395

Number of words in discussion: 148

Keywords: Drug metabolism, gut microbiota, gastrointestinal tract, in vivo, in silico. 


\section{Abbreviations:}

cgr: Cardiac glycoside reductase

CYP450: Cytochrome P450

H.pylori: Helicobacter pylori

HFA: Human flora-associated

HMP: Human Microbiome Project

LDL: Low-density lipoproteins

MDM: Microbiome-Derived Metabolism

MetaHIT: Metagenomics of the Human Intestinal Tract

NIH: National Institutes of Health

NSAID: Nonsteroidal anti-inflammatory drugs

PBPK: Physiologically based pharmacokinetic modeling and simulation

p-cresol: Para-cresol

SHIME: Simulated human intestinal microbial ecosystem

SN-38G: SN-38 glucuronide

Th1: 1 T helper

Th17: 17 T-helper 


\begin{abstract}
:
Increasing evidence uncovers the involvement of gut microbiota in the metabolism of numerous pharmaceutical drugs. The human gut microbiome harbours 10-100 trillion symbiotic gut microbial bacteria that utilize drugs as substrates for enzymatic processes to alter host metabolism. Thus, microbiota-mediated drug metabolism can change the conventional drug action course and cause inter-individual differences in efficacy and toxicity, making it vital for drug discovery and development. This review focuses on drug biotransformation pathways and discusses different models for evaluating gut microbiota role in drug metabolism.
\end{abstract}




\section{Significance statement:}

This review emphasizes the importance of gut microbiota and different modes of drug

metabolism mediated by them. It provides information on in vivo, in vitro, ex vivo, in silico and multi-omics approaches for identifying the role of gut microbiota in metabolism. Further, it highlights the significance of gut microbiota mediated metabolism in the process of new drug discovery and development as a rationale for safe and efficacious drug therapy. 


\section{Introduction}

Metabolism is the aggregate of all the chemical processes that occur in the body, and it comprises of anabolism and catabolism by enzymatic conversion of one chemical entity to another(Ritter et al., 2018). Drug metabolism involves an enzyme catalyzed biochemical process that transforms lipophilic drugs into more polar and readily excretable metabolites, leading to the termination or alteration of the drugs biological activity(Katzung, 2012). Drug metabolizing enzymes are present in abundance in the liver and play a crucial role in the metabolism of xenobiotics. They are also present in other sites such as kidneys, mucosa of the gastrointestinal tract, lungs, brain and skin but contribute less to the drug metabolism(Krishna and Klotz, 1994). In addition to the metabolic enzymes present in host cells, similar enzymes produced by intestinal microorganisms are implicated in the metabolism of several drug compounds. Gut microbiota is the multitude of bacteria, archaea, eukarya and viruses colonizing the adult human gastrointestinal tract with an approximate count of 100 trillion, that outnumbers the microbial count associated with body surfaces and is nearly 10 times greater than the total number of somatic and germ cells in the human body(Bäckhed et al., 2005). The collective genome of gut microbiota is termed microbiome and is approximately 100 times the number of genes compared to the human genome(Gill et al., 2006). Moreover, recent estimates show that the number of human cells $\left(3 * 10^{13}\right)$ and bacterial cells $\left(3.8^{*} 10^{13}\right)$ in the human body is of the same order, and the total mass occupied by the bacterial cells accounts for about $0.2 \mathrm{Kg}($ Sender et al., 2016).

Research in the field of metabolic capabilities of gut microbes has expanded concerning their effect on the efficacy and toxicity of drugs(Sousa et al., 2008). Co-evolving with the host, the microbiota is now viewed as a virtual organ with properties worthy of being combined with the host physiology(Evans et al., 2013). The United States NIH started an initiative, HMP, to 
understand the gamut of human genetics and physiological differentiation, the microbiome, and all aspects that affect the distribution transformation of the microorganisms in the body. It also involves the study of microflora related to human health and diseases. Another well-known European Union project on MetaHIT targets the gut microbiota in human health and associated metabolic activities of the microorganisms. Hence, the HMP and MetaHIT project are logical extensions of the Human Genome Project to characterize microbial populations colonizing healthy individuals(Turnbaugh et al., 2007; Metagenomics of the Human Intestinal Tract | METAHIT Project | FP7 | CORDIS | European Commission, n.d.). This review discusses gut microbes, their role in drug metabolism, and the experimental approaches used to elucidate them.

\section{Gut Microbiota: composition and physiological functions}

Fetal gut was previously considered sterile, but recent studies have indicated that early microbial exposure begins in utero as demonstrated by the distinct low diversity microbial compositions found in the placenta and meconium(Rautava et al., 2012; Nuriel-Ohayon et al., 2016). By the age of 2-5 years, gut microbiota in a child resembles that of an adult concerning diversity and composition. The gut microbial composition is shaped by the mode of delivery, type of infant feeding, gestational age, antibiotic use, environment, lifestyle, and host genetics(Rodríguez et al., 2015). The upper gut has an antimicrobial climate due to gastric acid and bile salts and the slow rate of movement of intestinal contents, thus making the large intestine the prime site for microbial colonization (Macfarlane and Macfarlane, 2009). Gram-positive Firmicutes and gramnegative Bacteroidetes constitute the dominant bacterial phyla found in the gut whereas, methanogenic archaea, eukaryotes like yeasts and viruses, Actinobacteria, Proteobacteria, Fusobacteria, and Verrucomicrobia are the minor bacterial phyla that are identified in the 
gut(Eckburg et al., 2005; Lozupone et al., 2012). Disruption of healthy gut microbiota (dysbiosis) has been implicated in the pathogenesis of various inflammatory and metabolic disorders; nevertheless, healthy gut microbiota plays an essential role in human physiology by carrying out numerous metabolic functions such as fermentation of indigestible carbohydrates, biosynthesis of vitamin $\mathrm{K}$ and vitamin $\mathrm{B}_{12}$, production of hormonal mediators and neurotransmitters, metabolism of bile salts and xenobiotics. Microbes also perform protective functions like providing resistance to colonization by pathobionts, modulating intestinal barrier functions, and promoting immune homeostasis(LeBlanc et al., 2013; Natividad and Verdu, 2013; Bäumler and Sperandio, 2016; Pickard et al., 2017; Molinero et al., 2019).

\section{Drug metabolism by the gut microbiota}

An emerging need to consider drug metabolism by gut microbiota as a crucial factor in drug discovery and development is unveiling. Drugs metabolized by gut microbiota may cause interindividual differences in the drug response. Moreover, drug administration by diverse routes can encounter metabolism by gut microbes; for example, orally administered drugs remain unabsorbed in the upper gut. Instead, the intestinal microbes act upon a modified-release preparation that reaches the large intestine for their metabolism. Drugs that bypass the absorption process can still reach the gut microbiota through biliary excretion and undergo metabolism. In addition, rectally administered drugs are prone to microbial metabolism due to their proximity to the gut microbes(Sousa et al., 2008). The potpourri of microbial species metabolize many drugs leading to altered bioavailability, toxicity, and adverse drug reactions affecting therapeutic efficacy referred to as MDM (Microbiome-Derived Metabolism). 
However, poor attention is given to understanding the pharmacokinetics of drugs affected by MDM(Javdan et al., 2020). The potential benefit of MDM is the activation of certain prodrugs, such as the conversion of azo drugs prontosil and neoprontosil to an active sulphanilamide moiety(Gingell et al., 1969). Oral co-administration of anti-viral drug sorivudine and anti-cancer drug 5-fluorouracil (5-FU) was the cause of acute deaths in eighteen patients. This lethality resulted from soaring levels of 5-FU due to the inhibition of hepatic enzyme-dihydropyrimidine dehydrogenase responsible for the metabolism of 5-FU by (E)-5-(2-bromovinyl)uracil, a metabolite of sorivudine produced by gut microbiota(Okuda et al., 1998).

\section{Modes of drug metabolism by the gut microbiota}

Gut microbiota can cause drug metabolism in several ways, including direct interaction with the drug or indirect action by intermeddling with the host metabolism. Figure 1 depicts the different modes of drug metabolism by gut microbiota.

\subsection{The direct effect of gut microbiota on drug metabolism}

The gut microbiota expresses an extensive array of drug-metabolizing enzymes like oxidoreductases, hydrolases, and lyases(Koppel et al., 2017). The activity of these enzymes leads to alteration of bioactivity of the drug, such as activation, deactivation or reactivation of drug, or conversion of the drug to a toxic metabolite(Wilkinson et al., 2018; Hitchings and Kelly, 2019).

\subsubsection{Activation of drug}

A prodrug is an inactive drug that converts into an active form after metabolism. Although the liver performs most of the metabolic processes, the enzymes produced by the gut microbiota also actuate the conversion of the prodrug to its active form. For 
instance, prodrugs protonsil and neoprotonsil are transformed into the active sulfanilamide moiety by azoreductases, a gut microbial enzyme(Gingell et al., 1969). Substantial conversion of the neoprotonsil to sulfanilamide occurs in the gut, as evidenced by the excretion of a significant percentage of unchanged drug in bile after its intraperitoneal injection. Further, antibiotic-treated rats had less sulfanilamide excretion, implicating gut microbial enzymes role in azo-reduction of the drugs(Gingell et al., 1971). Azoreductases cleave Azo bond in sulfasalazine, balsalazide and olsalazine releasing sulfapyridine and 5- amino salicylic acid (5-ASA). 5-ASA is an active moiety responsible for anti-inflammatory activity and used in the treatment of ulcerative colitis(Peppercorn and Goldman, 1972; Crouwel et al., 2021). Although probiotic treatment increased the azoreductase activity and plasma concentration, it failed to affect the pharmacokinetic parameters of sulfasalazine(Lee et al., 2012). Thioguanine (TG) and mercaptopurine (MP) are used in treatment of lymphoblastic leukaemia as immunomodulating agents. E. coli strain DH5 $\alpha$ in the gut microbiota metabolizes TG and MP to 6-TGN by hypoxanthine phosphoribosyl transferase (HPRT)(Movva et al., 2016). The immunosuppressive action occurs due to interaction between DNA and phosphorylated 6-thioguanine nucleotide (6-TGN), an active metabolite of thiopurines, during replication(de Boer et al., 2018; Crouwel et al., 2021). In addition, colonic microbiota improved the chronic colitis by TG even in the absence of host-mediated conversion of TG to 6-TGN by HPRT, suggesting that the local gut microbiota mediated transformation can help in targeted therapy for Crohn's and ulcerative colitis(Oancea et al., 2017). Another interesting recent example is Chinese herbal medicine, berberine, 
which undergoes drug activation upon conversion to oxyberberine by gut microbiota that helps treat gastric colitis(Li et al., 2020).

\subsubsection{Deactivation of drug}

The active form of the drug can lose its therapeutic efficacy due to the deactivating action of gut microbial enzymes. Lindenbaum et al. performed an experiment in volunteers which showed that the formation of dihydrodigoxin, a reduced inactive metabolite of cardiac glycoside digoxin, was subject dependent(J. Lindenbaum et al., 1981). Further experimentation in volunteers displaying substantial levels of reduced metabolites showed that co-administration of erythromycin reduces the excretion of the dihydrodigoxin(John Lindenbaum et al., 1981). After examining hundreds of microbial isolates, Eggerthelalenta, a common anaerobic inhabitant of the gut, was the sole microbe responsible for this type of reduction. However, the mere presence of this microorganism in the gut cannot guarantee the inactivation of digoxin to dihydrodigoxin in in vivo(Dobkin et al., 1982; Saha et al., 1983). An investigation later showed that a two-gene $\operatorname{cgr} 1$ and $\operatorname{cgr} 2$ operon was present in the strain of E. lenta, reducing digoxin and their expression was necessary for the reduction reaction. Digoxin upregulates the $\operatorname{cgr}$ operon, whereas arginine inhibits it. Arginine repressed the expression of cgr operon, thus inhibiting digoxin reduction, which is explicated by higher digoxin levels in the serum and urine of gnotobiotic mice. And these mice are colonized with digoxin reducing E. lenta strain on a high protein diet. The serum and urine levels of digoxin in mice colonized by non-reducing strains remain unaffected. This was a unique case where dietary intervention reverses the metabolism by gut microbes(Haiser et al., 2013).

\subsubsection{Conversion of a drug to a toxic metabolite}


Metabolizing enzymes produced by gut microbiota can form toxic intermediates, although rare, but can lead to adverse drug reactions. For example, a study was performed on rats to investigate the involvement of gut microbiota in the metabolism of a hypnotic drug-nitrazepam and its teratogenic effect. Administration of large doses to pregnant rats displayed teratogenic effects. Even though nitrazepam was co-metabolized by liver and gut microbiota, antibiotic treatment sharply decreased the excretion of reduced metabolites and diminished the fetal aberrations(Takeno and Sakai, 1991). The investigation later concludes that nitrazepam-related teratogenicity depended on the reduction step, which converted nitrazepam to 7 -aminonitrazepam. The reduction was catalyzed by an enzyme, nitroreductase, expressed by the gut bacterium Clostridium leptum(Rafii et al., 1997). There is unclear evidence about the role of gut microbiota in cisplatin-induced liver toxicity, but co-administration of antibiotics and cisplatin resulted in the reduction of hepatoxicity; thus, confirming the gut microbiota role in cisplatininduced liver toxicity(Gong et al., 2021).

\subsubsection{Reactivation of drug}

Enterohepatic recycling includes biliary excretion followed by intestinal reabsorption of the drug or its metabolites. In biliary excretion, drugs and metabolites are secreted and concentrated in the bile. Later, they are released from the gall bladder and drained into the intestine, where reabsorption occurs. Figure 2 represents the enterohepatic recycling of drugs, including those released by the de-conjugating action of bacterial enzymes. Reabsorption may convert the inactive form of the drug or its metabolite to an active form(Dobrinska, 1989). Enterohepatic cycling causes the plasma drug concentration-time profile to rise after specific time intervals, termed the "multiple peaking" phenomenon, 
and it significantly affects pharmacokinetic parameters(Malik et al., 2016). One of the plausible causes of intestinal injury is NSAIDs such as diclofenac, where the cleavage of one of its metabolites, diclofenac-1- $\beta-\mathrm{O}$-acyl glucuronide to diclofenac by the action of bacterial $\beta$-glucuronidase in the gut. Recurrent exposure of enterocytes to the resulting product of glucuronide hydrolysis (aglycone) could cause local tissue injury and marks the beginning of enteropathy(Saitta et al., 2014). LoGuidice et al. undertook a study in mouse models of NSAID enteropathy and demonstrated that administration of selective bacterial $\beta$-glucuronidase inhibitors reduces the exposure of intestinal mucosa to the aglycone and provided protection against diclofenac-induced enteropathy(LoGuidice et al., 2012). Anti-cancer drug irinotecan (CPT-11) is an excellent example of the reactivation of drugs caused by gut microbial enzymes. SN-38 is the prodrug irinotecan's active metabolite, glucuronidated in the liver to $\mathrm{SN}-38 \mathrm{G}$ and secreted in the bile. After reaching the intestine, $\beta$-glucuronidases of gut bacteria reconvert $\mathrm{SN}-38 \mathrm{G}$ to $\mathrm{SN}-38$, responsible for the irinotecan-induced severe diarrhoea(Takasuna et al., 1996).

\subsection{Effect on drug metabolism via host function modulation}

\subsubsection{Binding of the drug to microbial cells}

Bacterial cells express adhesive proteins called adhesins and are responsible for binding to the host cells. Adhesins are also known to interact and directly bind to the drug molecules, decreasing microbial binding to host cells and altering drug pharmacokinetics. Parkinson's disease is characterized by the loss of dopaminergic neurons in the substantia nigra and the presence of intracellular aggregates of $\alpha$ synuclein(Poewe et al., 2017). Levodopa, an immediate precursor of dopamine, is given to patients to relieve the symptoms. A small percentage of levodopa that escapes 
peripheral decarboxylation crosses the blood-brain barrier and is taken up by functioning dopaminergic neurons. Niehues et al. designed an in vitro study to test the hypothesis that the presence of H.pylori in patients with Parkinson's disease treated orally with levodopa can affect the plasma level of levodopa(Pierantozzi et al., 2001; Narozanska et al., 2014). The study revealed that adsorption of levodopa to bacteria surface is possible, and such interactions with levodopa results in the blocking of the proteins with adhesive properties, causing a lowered adhesion of H.pylori to gastric epithelial cells(Niehues and Hensel, 2009). The interaction between levodopa and H.pylori affects the pharmacokinetics of levodopa, i.e., it reduces the absorption and lowers plasma levels. Direct chemical transformation of levodopa by intestinal microbes has also been reported in patients with parkinsonism and rat models(Sandler et al., 1969; Goldin et al., 1973; Niehues and Hensel, 2009).

\subsubsection{Alteration in the absorption of drugs caused by gut microbiota}

Gut microbiota and their metabolites can change the local microenvironment in the human gut, altering the absorption of drugs(Enright et al., 2016). Zou et al. screened 136 drug excipients for their inhibitory potential of the intestinal transporter, OATP2B1. Out of the 24 potent inhibitors of the OATP2B1 identified, 8 of them are azo dyes. Administration of FD\&C Red No. 40 in mice, a red azo dye, decreased plasma levels of fexofenadine, a substrate for Oatp2B1, due to Oatp2B1 inhibition. However, the gut microbial isolates from diverse unrelated healthy humans metabolized azo dye to inactive metabolites that lack OATP2B1 inhibition. Thus, altering drug absorption by the gut microbiome proved beneficial in this case(Zou et al., 2020). 


\subsubsection{Competition of microbial metabolites with the drug or host metabolites for host}

\section{metabolic enzymes}

Competition for active sites of host metabolic enzymes amongst drug or its metabolites and gut microbial metabolites varies the drug's therapeutic efficacy. Metabolism of acetaminophen occurs by three means: a) conjugation with glucuronide catalyzed by UDP-glucuronosyltransferases, b) sulfate conjugation catalyzed by sulfotransferases, and c) oxidative metabolism through the CYP450enzymes(McGill and Jaeschke, 2013). The oxidative metabolic product formed primarily by the CYP2E1, N-acetyl-p-benzoquinone imine, is highly reactive in nature as it covalently binds to the thiol groups on proteins causing cellular oxidative stress(Vermeulen et al., 1992). As a result, it rapidly conjugates with intracellular glutathione producing a nontoxic glutathione conjugate and excreted as cysteine and mercapturic acid conjugates(Larson, 2007). p-cresol is a product of tyrosine fermentation produced by anaerobic gut microbes belonging to Coriobacteriaceae and Clostridium clusters XI and XIVa(Smith and Macfarlane, 1997; Saito et al., 2018). Clayton et al. used acetaminophen to test the applicability of pharmacometabonomic study in man. The research done on 99 healthy male volunteers inferred that pre-dose urine level of pcresol sulfate was inversely related to the post-dose ratio of acetaminophen sulfate to acetaminophen glucuronide. Thus, competition between p-cresol and acetaminophen for the active site of sulfotransferase reduces the effective systemic capacity of the individual to produce acetaminophen sulphate(Clayton et al., 2009). Moreover, computational chemistry has also established that cresols compete with acetaminophen for aryl sulfotransferase active site(DiGiovanni et al., 2013). This competition may 
lead to a toxic build-up of acetaminophen in case of acetaminophen overdose and result in hepatotoxicity. Another study deduced that the total excretion of acetaminophen conjugates remain constant to a great extent in germ-free and conventional housed mice, i.e. lowered sulfonation was compensated by improved glucuronidation(Possamai et al., 2015). However, this subject matter requires further investigation.

\subsubsection{Modification of host gene expression}

Despite the absence of direct contact between the liver and gut microbiota, they modulate hepatic gene expression of crucial genes playing a vital role in drug metabolism(Björkholm et al., 2009). Gene expression studies conducted on microarrays from germ-free (GF) and conventionally raised (CV) specific pathogenfree mice demonstrated differential expression of 112 genes among them, affecting the liver metabolic functions. In GF mice, genes regulated by constitutive androstane receptors showed higher expression. In contrast, CYP2B9 and CYP4A14 expressed to a lower extent in CV mice. The enhanced metabolism with shorter-term pentobarbitalinduced anesthesia further ascertained differential expression in GF compared to $\mathrm{CV}$ mice(Björkholm et al., 2009). Moreover, immunoblotting experiments in GF and CV rats revealed that gut microbiota moderately affects the levels of Phase II xenobioticmetabolizing enzymes in the large intestine and liver but remain unaffected in the small intestine(Meinl et al., 2009). mRNA profiling in the four intestinal sections and liver for the expression of xenobiotic-processing genes (XPGs) in CV and GF mice elucidated that the GF mice expressed 116 XPGs in at least one intestinal section, but 133 XPGs were unaffected. Also, the liver and intestine of GF mice showed 
downregulation of CYP3A that may result in altered metabolism of xenobiotics $(\mathrm{Zd}$ et al., 2016; Fu et al., 2017). Administration of a VSL3, a commercial probiotic mixture containing eight live strains of bacteria to $\mathrm{CV}$ and GF mice was investigated. In $\mathrm{CV}$ mice, VSL3 enhanced the mRNAs expression for CYP4V3, alcohol dehydrogenase 1, and carboxyesterase $2 \mathrm{a}$, and declined for multiple phase II glutathione-S-transferases, whereas, in GF mice it reduced the mRNAs expression for UDPglucuronosyltransferases $1 \mathrm{a} 9$ and 2a3(Selwyn et al., 2016). In conclusion, gut microbiota modulates the expression of XPGs leading to altered xenobiotic metabolism.

\subsubsection{Immunomodulation}

Gut microbiota can impact the efficacy of chemotherapeutic drugs by translocation and immunomodulation. For instance, the anti-cancer drug cyclophosphamide caused the shortening of small intestinal villi and disrupted the intestinal barrier function(Alexander et al., 2017). These disruptions led to the translocation of several commensal gram-positive bacteria such as Lactobacillus johnsonii, Lactobacillus murinus and Enterococcus hirae into the secondary lymphoid organs in the mice(Viaud et al., 2013). that resulted in stimulation of the differentiation of naive $\mathrm{CD}^{+} \mathrm{T}$ cells to cause accumulation of type Th17 and type Th1 cell responses. GF mice and mice treated with antibiotic vancomycin deplete gram-positive bacteria that lowers the Th17 response and inhibit the antitumor effect of cyclophosphamide(Viaud et al., 2011, 2013). Effectiveness of gut microbiota in immune checkpoint blocked cancer therapy is proven in periclinal models and cancer patients for Akkermansia 
muciniphila, Bacteroides fragilis, Bifidobacterium spp. and Faecalibacterium spp(Gopalakrishnan et al., 2018; Routy, Gopalakrishnan, et al., 2018; Routy, Le Chatelier, et al., 2018). The immune checkpoint blocked therapy targets cytotoxic $\mathrm{T}$ lymphocyte protein-4, blockade of programmed death-1 (PD-1) protein, and programmed death-ligand 1 (PD-L1)(Sivan et al., 2015; Farrokhi et al., 2019). Table 1 summarises the gut microbiota biotransformation reactions.

\section{Experimental approaches to analyze the metabolism of drugs by gut microbiota}

Different approaches are utilized to analyze gut mediated metabolism. Table 2 gives examples of drug metabolism investigated using different approaches. Figure 3 elucidates the experimental approaches to analyze the metabolism of drugs by gut microbiota.

\subsection{In vivo approaches}

\subsubsection{Murine models}

Since the beginning of research in gut microbiota, mice models have been widely used due to their anatomical, physiological and genetic similarities to humans. Mice models allow approaches that require invasive sampling methods that would be considered unethical in human subjects. They have added advantages such as small size, high reproductive rate, and low maintenance cost(Hugenholtz and de Vos, 2018). Similar to humans, gut microbiota in mice is also dominated by Bacteroidetes and Firmicutes phyla. Nevertheless, there lies a variation in the plethora of microorganisms at the genera level. Prevotella, Faecalibacterium, and Ruminococcus genera have a relatively higher abundance in the human gut, whereas Lactobacillus, Alistipes, and Turicibacter genera occupy a relatively higher proportion of mouse gut 
microbiota(Nguyen et al., 2015). Animal models cannot accurately recapitulate human microbial repertoire, curbing direct extrapolating results from conventionally raised mice to humans.

Germ-free mice are reared in an isolator to ensure the complete absence of detectable microbes. Also, germ-free mice have enlarged caecum, reduced villous thickness and also show under-developed intestine-associated lymphoid tissue(Taguer and Maurice, 2016; Sun et al., 2019). Difficulty in generating and maintaining germ-free mice has led to an alternative antibiotic use to deplete mice gut microbiota. Some antibiotics can target a particular subset of microorganisms, such as metronidazole and clindamycin deplete anaerobes(Kennedy et al., 2018). Gnotobiotic mice, colonized by one or more defined microbial species, simplify the complex host-microbial interactions. Other animals such as rats, pigs, dogs and guinea pigs serve as an alternative to mice experiments. Thus, comparing metabolites in gnotobiotic mice and conventionally raised mice provides valuable insights into drug metabolism by gut microbes. HFA (Human flora-associated) animals were used to understand the role of human intestinal microbes in drug metabolism. They were created by inoculating germ-free animals with human faecal matter(Hirayama and Itoh, 2005). However, using the HFA animal models has several drawbacks; factors such as genetics and diet of the recipient animals have been found to affect colonization of the rodent gut by human bacterial communities. For instance, HFA mice display a lower Firmicutes to Bacteriodetes ratio than donor human or HFA rats(Wos-Oxley et al., 2012). However, despite its flaws, the establishment of human gut flora into the intestines of animals is 
known to yield a stable model with a better resemblance to microbial metabolism in the human gut.

\subsubsection{Other animal models}

Invertebrate Caenorhabditis elegans, a free-living bacterivorous nematode, is a simplified in vivo model to study drug metabolism by microbiota. This model was used to show that bacterial ribonucleotide metabolism can cause activation of fluoropyrimidine drugs like 5-fluorouracil(Scott et al., 2017). A vertebrate zebrafish also serves as a model of intermediate gut microbial diversity that is more complex than invertebrates and less complex than that of mammals. Some significant advantages of this alternative testing model include their small size, high fecundity, external fertilization, rapid development, transparency and low cost. In addition, microbe-free embryos of zebrafish can be colonized with a required strain of microbial species by simple immersion in water(axenic zebrafish) and used as an in vivo model to study the effects of drug metabolism by microbiota(Catron et al., 2019).

\subsection{In vitro approaches}

\subsubsection{Cell-culture}

In vivo studies utilizing human and animal models are inappropriate for routine and large-scale screening of xenobiotic metabolism by gut microbiota due to ethical, economic and time restrictions. In vitro models such as culturing representative strains of gut microbiota with the drug have been used to study microbial drug biotransformation. Although both in vitro and ex vivo studies require laboratory experimentation setup, they differ in the source of the microbial sample used. In vitro 
studies use microbial samples that are isolated from an organism instead of laboratory microbial strains(Read "Environmental Chemicals, the Human Microbiome, and Health Risk: A Research Strategy" at NAP.edu, 2021). In vitro models allow differentiation of microbial xenobiotic metabolism from that of host metabolic activities. In vitro fermentation models can range from simple static batch cultures to multistage continuous cultures systems that utilize chemostats to match the dynamic equilibrium of the gut. Culture models require suitable culture media and environmental conditions such as the anaerobic chamber, temperature and $\mathrm{pH}$ controls(Payne et al., 2011). Drugs are introduced into the fermentation systems, and aliquots removed at defined time points are quantitatively analyzed for the depletion of substrate and appearance of metabolites to determine the rate and extent of drug metabolism by gut microbiota. In such models, adaptation to specific culture conditions may cause deviation in the bacterial composition over time(Payne et al., 2011). These model designs prevent the extension of information regarding the drug's pharmacokinetics in the upper gastrointestinal tract; besides, they neglect the interactions between the host tissue and microbiota, which are essential for the drugs co-metabolized by the host and microbes(Hu et al., 2019). An in vitro fermentation model for investigating exopolysaccharides effect on gut microbiota showed that exopolysaccharides are transformed into short-chain fatty acids. Furthermore, 16S rDNA sequencing elucidated that exopolysaccharides increased the abundance of Ruminococcus, Dorea, Butyricicoccus, and Blautia(Zhu et al., 2021).

\subsubsection{Simulators}

Complex simulators of the intestine, such as the SHIME reactor have been developed 
to mimic the gut microbial environment. SHIME is a validated five-stage model in which a two-step fill-and-draw system simulates the small intestine while the latter three reactors mimic the large intestine. When inoculated with microorganisms, each reactors hosts intestinal region-specific distinctive microbial communities. All the reactors are connected in series employing pumping systems and placed under welldefined and controlled conditions(Molly et al., 1993). One validation test for the SHIME model involves converting prodrug sulfasalazine to its active moiety 5aminosalicylic acid. Results stated that only a small percentage of 5-aminosalicylic acid was released up to the end of vessel 2 (small intestine). At the same time, a complete transformation happened at the beginning of vessel 3 (large intestine)(Molly et al., 2009). The disadvantage of this model is that the bacterial miscellany in the colon mucosa is under-represented in the faecal inoculum(Durbán et al., 2011). Therefore, an up-gradation, mucosal-SHIME (M-SHIME), was introduced in the SHIME model, which had an advantage over the older SHIME model. This optimization of SHIME considers the luminal microbiota and the colon mucosaassociated microbial communities by incorporating mucin-covered microcosms(Van den Abbeele et al., 2012).

\subsubsection{Microfluidic devices (organ-on-chip systems)}

Organ-on-a-chip models consist of continuous perfusion of microchambers that are amenable to the inhabitation of cultured living cells to simulate tissue- and organ-level physiology(Bhatia and Ingber, 2014). Gut-on-a-chip models comprised two hollow chambers separated by an extracellular matrix coated by a porous membrane of polyester or polycarbonate and lined with human intestinal epithelial cells. In some 
studies, the microenvironment of the cells is recreated by control of culture medium flow rate through the microchannels and, in other studies, by applying cyclic strain to cause peristalsis like deformations(Kim et al., 2012). A handful of microbiota-related studies have been done using microfluidic devices that demonstrate the ability of differentiated epithelial cells to sustain the growth of intestinal inhabitants. Lactobacillus rhamnosus GG host-pathogen interactions and interaction among components of the intestine, the immune system and bacteria(Kim et al., 2010, 2012; HJ Kim et al., 2016). These models with fluidic control can permit controlled delivery of desired concentration of drugs dissolved in medium to the intestinal epithelium cocultured with microbes to investigate microbiota-based drug metabolism in a biomimetic system(Tanaka et al., 2006; Vickerman et al., 2008). However, replicating all the intestinal wall layers and co-culturing total microbiota rather than single microbial species or microbial consortia are some of the challenges yet to be explored(Lee et al., 2019). Shah et al. presented a modular, microfluidics-based model HuMix (human-microbial crosstalk) that allows co-culturing of human and microbial cells under representative gastrointestinal human-microbe interface conditions. The individual transcriptional responses from human epithelial cells co-cultured with Lactobacillus rhamnosus GG under anaerobic conditions inside HuMix are in accordance with in vivo data. In addition, human epithelial cells co-cultured with Bacteroides caccae and LGG elicit a transcriptional response differing from a coculture containing only LGG, suggesting the use of HuMix in molecular interactions between host and host microbiome(Shah et al., 2016). 


\subsection{Ex vivo approaches}

In contrast to in vitro studies, ex vivo studies use biological material comprising microbes in an artificial setting. For example, multiple studies utilize ex vivo fermentation systems inoculated with human or animal faecal homogenates or animal caecal to screen drug metabolism by microbes(E et al., 2018). This allows drug screening against a greater diversity of microorganisms present in the faecal/caecal contents.

\subsubsection{Fecalase or caecalase assay}

This research tool makes use of a cell-free extract of faecal or caecal contents, fecalase or caecalase assays. Lysis of bacterial cells in faecal suspension by passing through a homogenizer or sonication followed by removing cell debris by centrifugation yields a stable extract that retains the enzyme fraction of bacteria(Tamura et al., 1980). The fecalase assay assesses the conversion of amlodipine to pyridine metabolite. The pyridine metabolite concentration increased with incubation time, suggesting the role of gut microbiota in amlodipine metabolism and further confirmed by a pharmacokinetic study demonstrating an increase in bioavailability of amlodipine in antibiotic-treated mice compared to control mice(Yoo et al., 2016). However, diet and physiological factors have affected fecalase and caecalase activity, leading to intraand inter-individual differences(Yeo et al., 2012).

\subsubsection{Organoids}

Scientific advancement has led to the development of three-dimensional ex vivo multicellular tissue constructs derived from human stem cells containing organspecific cell types termed organoids(de Souza, 2017; Min et al., 2020). Intestinal and gastric organoids have been used to examine the crosstalk between infectious 
pathogens such as Salmonella typhimurium, Helicobacter pylori, rotavirus and the luminal epithelium(Finkbeiner et al., 2012; Bartfeld et al., 2015; Forbester et al., 2015). Engineered gastrointestinal organoids microinjected with microbiota can decipher the mechanism of drugs action and microbiota-based metabolism. Cell culture and simulator models are insufficient to represent host cell impact on microbiota physiology that can be overcome using the organoid model(Hill et al., 2017). The intestinal epithelial organoid is a novel model to study host-microbiota interactions. Investigation on the effect of short-chain fatty acids produced by commensal gut bacteria with the metabolites of Akkermansia muciniphila and Faecalibacterium prausnitzii revealed that Akkermansia muciniphila metabolites affect transcription factors and genes (Fiaf, Gpr43, histone deacetylases, and peroxisome proliferator-activated receptor-gamma) associated with cellular lipid metabolism and growth. In contrast, Faecalibacterium prausnitzii has a weak effect on host transcription(Lukovac et al., 2014).

\subsection{In silico approaches}

Technological advances have resulted in efficacious computational tools to predict drug pharmacokinetics in the human body. Despite the difficulty in modelling complex biochemical reactions, multiple computational tools have been developed to predict microbial xenobiotic metabolism. The complexity arises from the non-specificity of many microbial enzymes for substrates and vast microbiota diversity at the species and community level(Klünemann et al., 2014). PBPK models describe the whole-body drug kinetics by using compartments corresponding to the body's organs connected by a circulating blood system(Zhuang and Lu, 
2016). However, PBPK models were unable to account for microbial metabolism until the recent inclusion of the microbiome component in the intestinal compartment. Therefore, a PBPK model was devised that accurately predicts and separates brivudine's host and microbiome mediated metabolism to its hepatotoxic metabolite bromovinyluracil. For constructing the model, the kinetic parameters of the drug and its metabolite were obtained in various compartments over time in the presence and absence of microbial drug metabolism(Zimmermann et al., 2019b). Besides, a generalized approach was developed by building models parametrized with drug and metabolite kinetics in germ-free and conventionally raised mice for two additional drugs, sorivudine and clonazepam(Zimmermann et al., 2019b). An example of a searchable resource is MicrobeFDT, in which networks of food compounds and drugs with similar structures are created and linked to microbial enzymes with known toxicities. Based on the postulation, if a microbial enzyme acts on one compound from a group, it may act on related compounds found in the group(Guthrie et al., 2021). A PBPK model-based study indicated that hydrolysis of intestinal glucuronide impacts the pharmacokinetics of aglycone. A PBPK model was developed to investigate the effect of intestinal glucuronide on the pharmacokinetics of an active compound SN-38 glucuronide considering liver and gut as the major eliminating organs. This twocompartment model suggested that hydrolysis of glucuronide in the gut increased the local intestinal exposure to the $\mathrm{SN}-38$, but the systemic exposure was insignificant(Wu, 2012; Guthrie and Kelly, 2019). Thus, results from in silico prediction tools can complement and improvise the experimental setup of in vitro studies.

\subsection{Multi-omics approach}


An ever-increasing knowledge of the microbiome impact on drug efficacy, disposition and toxicity, pharmacomicrobiomics (microbiome-drug interactions) were pioneered as an extension of pharmacogenetics(Mariam et al., 2010; Aziz et al., 2018; Sharma et al., 2019). Genetic diversity of the gut microbial communities has come to light due to the advent of next-generation sequencing techniques such as $16 \mathrm{~S}$ rRNA gene amplicon sequencing and shotgun metagenomics(Sanschagrin and Yergeau, 2014). Metagenomics, in addition, gives a peek at the potential functional capabilities of the microorganisms (Haiser and Turnbaugh, 2013). Nevertheless, the mere abundance of the gene cannot guarantee its expression. Metatranscriptomics, the sequencing of gene transcripts and meta-proteomics, the measurement of expressed proteins also form part of pharmacomicrobioics. Apart from solely detecting the microbial species present in large numbers, these techniques also distinguish the metabolically active gut microbes(Ursell and Knight, 2013; Xiong et al., 2015). Targeted or untargeted metabolomics and metabonomic analysis coupled with in vivo and in vitro experimental designs have proven valuable to determine the gut microbial contribution to drug metabolism(Aura et al., 2011; Yip and Chan, 2015). Metabolomic analysis has been used for targeted analysis of drug metabolites and to discover unique biomarkers that have helped predict the host response or the host metabolism of a drug. For instance, the pre-dose level of bacterial metabolite, $p$-cresol, influences the hepatic sulfate conjugation of acetaminophen(Clayton et al., 2009). A high throughput screening led to the identification of bacterial gene products that metabolize drugs. Integrated data obtained from relevant omic approaches such as untargeted metabolomics and metagenomics supports identifying the gene products. Moreover, the study demonstrated the ability of 76 gut bacterial species to metabolize 271 drugs belonging to a wide range of chemical classes(Zimmermann et al., 2019a). Even though the omic methods provide valuable 
information, using these techniques in elucidating drug metabolism by gut microbiota still has a long way to go.

\section{Toxicological assessment of drug metabolites}

As discussed earlier, microbial action may result in drug toxicity, and a meticulous study has been done on the intestinal toxicity caused by the activity of gut microbes on the anti-cancer drug irinotecan.SN-38, the active metabolite of the prodrug irinotecan, is glucuronidated in the liver to SN-38G and secreted in the bile. In the intestine, bacterially-derived $\beta$-glucuronidases converts $\mathrm{SN}-38 \mathrm{G}$ to $\mathrm{SN}-38$, responsible for the irinotecan-induced severe diarrhoea(Takasuna et al., 1996). The toxicity of drug metabolites produced by gut microbes is mainly evaluated by comparative clinical observations and histological examination of tissues of germ-free/antibiotictreated and conventionally raised/HFA animals. Other tools such as toxicity predicting software and omics technology for studying toxico-microbiomics are also used(Abdelsalam et al., 2020). The toxicity of short-lived reactive metabolites is analyzed by trapping the electrophilic metabolites with nucleophiles like glutathione and cyanide ions followed by the mass spectrometric analysis adducts formed(Tang and Lu, 2010). Manipulation in the gut microbial composition or metabolic activity can lower the production of toxic metabolites or improve the therapeutic outcomes. Wallace and co-author demonstrated that the administration of selective bacterial $\beta$-glucuronidase inhibitor protected mice from irinotecan-induced toxicity without killing the bacteria. This inhibitor would benefit cancer patients as it will selectively inhibit the bacterial $\beta$-glucuronidase and prevent the formation of $\mathrm{SN}-38$ that kills the microbiota essential for human health; hence, it will alleviate irinotecan-induced toxicity(Wallace et al., 2010). 


\section{Impact of drugs on the gut microbiome}

Several drugs such as proton pump inhibitors, statins, ACE inhibitors have demonstrated the ability to change the gut environment, thus affecting the composition, growth and functions of gut microbial communities(Weersma et al., 2020). For instance, metformin affects the composition and function of gut microbiota. Germ-free mice treated with gut microbiota from metformin-treated individuals showed lower blood glucose levels than those treated with gut microbiota from placebo-treated donors. This showed that metformin-altered gut microbiota improves glucose metabolism(Wu et al., 2017). High-throughput screening of over 1000 drugs covering a wide range of therapeutic classes was performed against 40 gut microbial strain isolates. Around 835 drugs acted upon molecular targets in human cells, and the rest were antiinfectives. Using drug concentrations similar to that estimated to be found in the gut for many drugs, the study showed that $27 \%$ of non-antibiotic suppressed the growth of at least one of the tested microbial strains(Maier et al., 2018). Thus, the interplay between gut microbiota and drugs is complex and bidirectional. 


\section{Conclusion}

Although gut microbiota-mediated drug metabolism was first discovered in the mid-20 ${ }^{\text {th }}$ century, research in this field has been challenging owing to the extensive and variable repertoire of gut microbes in individuals and the complicated mechanisms by which the microbes carry out drug metabolism. Furthermore, Microbially-derived drug metabolites can have a different potency than parent drugs or, in some cases, even a toxic potential, thus causing deviations from the expected therapeutic outcomes of the drug. Integrating experimental, computational, and multiomic approaches will deepen our understanding of gut microbial composition and recognize gut microbiota-mediated drug metabolism. Evaluation of drug metabolism by gut microbiota in new chemical entity drug discovery and development is rational for safe and efficacious drug therapy. Once the role of gut microbes in drug metabolism is established, the host-microbiota symbiotic relation exploration will help develop refined and personalized drug therapies with maximum therapeutic benefits and minimal toxicological effects. 


\section{Acknowledgements}

P.D., C.D. and K.G. are grateful to the Department of Pharmaceuticals, Ministry of Chemicals \& Fertilizers, Government of India, New Delhi, for the NIPER fellowship award. The manuscript bears the NIPER-Hyderabad communication number NIPER-H/2021/177. 


\section{Authorship contribution:}

Wrote or contributed to the writing of the manuscript: Pooja Dhurjad, Chinmayi Dhavaliker,

Kajal Gupta, Rajesh Sonti 


\section{Financial Disclosure}

No author has an actual or perceived conflict of interest with the contents of this article. 


\section{References:}

Abdelsalam NA, Ramadan AT, ElRakaiby MT, and Aziz RK (2020) Toxicomicrobiomics: The Human Microbiome vs. Pharmaceutical, Dietary, and Environmental Xenobiotics. Front Pharmacol 11:390

Alexander JL, Wilson ID, Teare J, Marchesi JR, Nicholson JK, and Kinross JM (2017) Gut microbiota modulation of chemotherapy efficacy and toxicity. Nat Rev Gastroenterol Hepatol 14:356-365.

Allgayer H, Ahnfelt NO, Kruis W, Klotz U, Frank-Holmberg K, Söderberg HN, and Paumgartner G (1989) Colonic N-acetylation of 5-aminosalicylic acid in inflammatory bowel disease. Gastroenterology 97:38-41.

Aura A-M, Mattila I, Hyötyläinen T, Gopalacharyulu P, Bounsaythip C, Orešič M, and OksmanCaldentey K-M (2011) Drug metabolome of the simvastatin formed by human intestinal microbiota in vitro. Mol Biosyst 7:437-446.

Aziz RK, Hegazy SM, Yasser R, Rizkallah MR, and ElRakaiby MT (2018) Drug pharmacomicrobiomics and toxicomicrobiomics: from scattered reports to systematic studies of drug-microbiome interactions. Expert Opin Drug Metab Toxicol 14:10431055.

Bäckhed F, Ley RE, Sonnenburg JL, Peterson DA, and Gordon JI (2005) Host-bacterial mutualism in the human intestine. Science 307:1915-1920. 
Bartfeld S, Bayram T, van de Wetering M, Huch M, Begthel H, Kujala P, Vries R, Peters PJ, and Clevers H (2015) In vitro expansion of human gastric epithelial stem cells and their responses to bacterial infection. Gastroenterology 148:126-136.e6.

Bäumler AJ, and Sperandio V (2016) Interactions between the microbiota and pathogenic bacteria in the gut. Nature 535:85-93.

Bhatia SN, and Ingber DE (2014) Microfluidic organs-on-chips. Nat Biotechnol 32:760-772.

Björkholm B, Bok CM, Lundin A, Rafter J, Hibberd ML, and Pettersson S (2009) Intestinal Microbiota Regulate Xenobiotic Metabolism in the Liver. PLoS ONE 4:e6958.

Boer J, Young-Sciame R, Lee F, Bowman KJ, Yang X, Shi JG, Nedza FM, Frietze W, Galya L, Combs AP, Yeleswaram S, and Diamond S (2016) Roles of UGT, P450, and Gut Microbiota in the Metabolism of Epacadostat in Humans. Drug Metab Dispos Biol Fate Chem 44:1668-1674.

Catron T, Gaballah S, and Tal T (2019) Using Zebrafish to Investigate Interactions Between Xenobiotics and Microbiota. Curr Pharmacol Rep 5:468-480.

Clark AM, Clinton RT, Baker JK, and Hufford CD (1983) Demethylation of imipramine by enteric bacteria. J Pharm Sci 72:1288-1290.

Clayton TA, Baker D, Lindon JC, Everett JR, and Nicholson JK (2009) Pharmacometabonomic identification of a significant host-microbiome metabolic interaction affecting human drug metabolism. Proc Natl Acad Sci 106:14728-14733. 
Crouwel F, Buiter HJC, and de Boer NK (2021) Gut Microbiota-driven Drug Metabolism in Inflammatory Bowel Disease. J Crohns Colitis 15:307-315.

de Boer NKH, Peyrin-Biroulet L, Jharap B, Sanderson JD, Meijer B, Atreya I, Barclay ML, Colombel J-F, Lopez A, Beaugerie L, Marinaki AM, van Bodegraven AA, and Neurath MF (2018) Thiopurines in Inflammatory Bowel Disease: New Findings and Perspectives. J Crohns Colitis 12:610-620.

de Souza N (2017) Organoid culture. Nat Methods 14:35-35.

Dobkin JF, Saha JR, Butler VP, Neu HC, and Lindenbaum J (1982) Inactivation of digoxin by Eubacterium lentum, an anaerobe of the human gut flora. Trans Assoc Am Physicians 95:22-29.

Dobrinska MR (1989) Enterohepatic circulation of drugs. J Clin Pharmacol 29:577-580.

Durbán A, Abellán JJ, Jiménez-Hernández N, Ponce M, Ponce J, Sala T, D’Auria G, Latorre A, and Moya A (2011) Assessing Gut Microbial Diversity from Feces and Rectal Mucosa. Microb Ecol 61:123-133.

E van de S, Fhj S, Rs O, C van W, Gs W, M H, Ihg N, and Whj V (2018) An Ex Vivo Fermentation Screening Platform to Study Drug Metabolism by Human Gut Microbiota. Drug Metab Dispos Biol Fate Chem 46:1596-1607.

Eckburg PB, Bik EM, Bernstein CN, Purdom E, Dethlefsen L, Sargent M, Gill SR, Nelson KE, and Relman DA (2005) Diversity of the Human Intestinal Microbial Flora. Science 308: $1635-1638$. 
Enright EF, Gahan CGM, Joyce SA, and Griffin BT (2016) The Impact of the Gut Microbiota on Drug Metabolism and Clinical Outcome. Yale J Biol Med 89:375-382.

Evans JM, Morris LS, and Marchesi JR (2013) The gut microbiome: the role of a virtual organ in the endocrinology of the host. $J$ Endocrinol 218:R37-47.

Farrokhi AS, Darabi N, Yousefi B, Askandar RH, Shariati M, and Eslami M (2019) Is it true that gut microbiota is considered as panacea in cancer therapy? J Cell Physiol 234:1494114950, John Wiley \& Sons, Ltd.

Finkbeiner SR, Zeng X-L, Utama B, Atmar RL, Shroyer NF, and Estes MK (2012) Stem cellderived human intestinal organoids as an infection model for rotaviruses. mBio 3:e0015900112.

Forbester JL, Goulding D, Vallier L, Hannan N, Hale C, Pickard D, Mukhopadhyay S, and Dougan G (2015) Interaction of Salmonella enterica Serovar Typhimurium with Intestinal Organoids Derived from Human Induced Pluripotent Stem Cells. Infect Immun 83:2926-2934.

Fu ZD, Selwyn FP, Cui JY, and Klaassen CD (2017) RNA-Seq Profiling of Intestinal Expression of Xenobiotic Processing Genes in Germ-Free Mice. Drug Metab Dispos Biol Fate Chem 45:1225-1238.

Gill SR, Pop M, DeBoy RT, Eckburg PB, Turnbaugh PJ, Samuel BS, Gordon JI, Relman DA, Fraser-Liggett CM, and Nelson KE (2006) Metagenomic Analysis of the Human Distal Gut Microbiome. Science 312:1355-1359. 
Gingell R, Bridges JW, and Williams RT (1969) Gut flora and the metabolism of prontosils in the rat. Biochem $J$ 114:5P-6P.

Gingell R, Bridges JW, and Williams RT (1971) The role of the gut flora in the metabolism of prontosil and neoprontosil in the rat. Xenobiotica Fate Foreign Compd Biol Syst 1:143156.

Goldin BR, Peppercorn MA, and Goldman P (1973) Contributions of host and intestinal microflora in the metabolism of L-dopa by the rat. J Pharmacol Exp Ther 186:160-166.

Gong S, Feng Y, Zeng Y, Zhang H, Pan M, He F, Wu R, Chen J, Lu J, Zhang S, Yuan S, and Chen X (2021) Gut microbiota accelerates cisplatin-induced acute liver injury associated with robust inflammation and oxidative stress in mice. J Transl Med 19:147.

Gopalakrishnan V, Spencer CN, Nezi L, Reuben A, Andrews MC, Karpinets TV, Prieto PA, Vicente D, Hoffman K, Wei SC, Cogdill AP, Zhao L, Hudgens CW, Hutchinson DS, Manzo T, Petaccia de Macedo M, Cotechini T, Kumar T, Chen WS, Reddy SM, Szczepaniak Sloane R, Galloway-Pena J, Jiang H, Chen PL, Shpall EJ, Rezvani K, Alousi AM, Chemaly RF, Shelburne S, Vence LM, Okhuysen PC, Jensen VB, Swennes AG, McAllister F, Marcelo Riquelme Sanchez E, Zhang Y, Le Chatelier E, Zitvogel L, Pons N, Austin-Breneman JL, Haydu LE, Burton EM, Gardner JM, Sirmans E, Hu J, Lazar AJ, Tsujikawa T, Diab A, Tawbi H, Glitza IC, Hwu WJ, Patel SP, Woodman SE, Amaria RN, Davies MA, Gershenwald JE, Hwu P, Lee JE, Zhang J, Coussens LM, Cooper ZA, Futreal PA, Daniel CR, Ajami NJ, Petrosino JF, Tetzlaff MT, Sharma P, Allison JP, Jenq RR, and Wargo JA (2018) Gut microbiome modulates response to antiPD-1 immunotherapy in melanoma patients. Science 359:97-103. 
Guo Y, Crnkovic CM, Won K-J, Yang X, Lee JR, Orjala J, Lee H, and Jeong H (2019) Commensal Gut Bacteria Convert the Immunosuppressant Tacrolimus to Less Potent Metabolites. Drug Metab Dispos 47:194-202.

Guthrie L, and Kelly L (2019) Bringing microbiome-drug interaction research into the clinic. EBioMedicine 44:708-715.

Guthrie L, Wolfson S, and Kelly L (2021) The human gut chemical landscape predicts microbemediated biotransformation of foods and drugs. eLife 8:e42866.

Haiser HJ, Gootenberg DB, Chatman K, Sirasani G, Balskus EP, and Turnbaugh PJ (2013) Predicting and manipulating cardiac drug inactivation by the human gut bacterium Eggerthella lenta. Science 341:295-298.

Haiser HJ, and Turnbaugh PJ (2013) Developing a metagenomic view of xenobiotic metabolism. Pharmacol Res 69:21-31.

Harris BE, Manning BW, Federle TW, and Diasio RB (1986) Conversion of 5-fluorocytosine to 5-fluorouracil by human intestinal microflora. Antimicrob Agents Chemother 29:44-48.

Hill DR, Huang S, Nagy MS, Yadagiri VK, Fields C, Mukherjee D, Bons B, Dedhia PH, Chin AM, Tsai Y-H, Thodla S, Schmidt TM, Walk S, Young VB, and Spence JR (2017) Bacterial colonization stimulates a complex physiological response in the immature human intestinal epithelium. eLife 6:e29132. 
Hirayama K, and Itoh K (2005) Human flora-associated (HFA) animals as a model for studying the role of intestinal flora in human health and disease. Curr Issues Intest Microbiol 6:69-75.

Hitchings R, and Kelly L (2019) Predicting and Understanding the Human Microbiome's Impact on Pharmacology. Trends Pharmacol Sci 40:495-505.

Hu Y, Chen H, Li P, Li B, Cao L, Zhao C, Gu Q, and Yin Y (2019) Analysis of Interactions between Endobiotics and Human Gut Microbiota Using In Vitro Bath Fermentation Systems. J Vis Exp JoVE 150:e59725.

Hugenholtz F, and de Vos WM (2018) Mouse models for human intestinal microbiota research: a critical evaluation. Cell Mol Life Sci 75:149-160.

Javdan B, Lopez JG, Chankhamjon P, Lee Y-CJ, Hull R, Wu Q, Wang X, Chatterjee S, and Donia MS (2020) Personalized Mapping of Drug Metabolism by the Human Gut Microbiome. Cell 181:1661-1679.e22.

Kaddurah-Daouk R, Baillie RA, Zhu H, Zeng Z-B, Wiest MM, Nguyen UT, Wojnoonski K, Watkins SM, Trupp M, and Krauss RM (2011) Enteric Microbiome Metabolites Correlate with Response to Simvastatin Treatment. PLoS ONE 6.

Katzung BG (2012) Basic and clinical pharmacology, Mc Graw Hill.

Kennedy EA, King KY, and Baldridge MT (2018) Mouse Microbiota Models: Comparing GermFree Mice and Antibiotics Treatment as Tools for Modifying Gut Bacteria. Front Physiol 9:1534. 
Kim HJ, Huh D, Hamilton G, and Ingber DE (2012) Human gut-on-a-chip inhabited by microbial flora that experiences intestinal peristalsis-like motions and flow. Lab Chip 12:2165-2174.

Kim HJ, Li H, Collins JJ, and Ingber DE (2016) Contributions of microbiome and mechanical deformation to intestinal bacterial overgrowth and inflammation in a human gut-on-achip. Proc Natl Acad Sci U S A 113:E7-15.

Kim IS, Yoo D-H, Jung I-H, Lim S, Jeong J-J, Kim K-A, Bae O-N, Yoo HH, and Kim D-H (2016) Reduced metabolic activity of gut microbiota by antibiotics can potentiate the antithrombotic effect of aspirin. Biochem Pharmacol 122:72-79.

Kim J, Hegde M, and Jayaraman A (2010) Co-culture of epithelial cells and bacteria for investigating host-pathogen interactions. Lab Chip 10:43-50.

Klünemann M, Schmid M, and Patil KR (2014) Computational tools for modeling xenometabolism of the human gut microbiota. Trends Biotechnol 32:157-165.

Koppel N, Rekdal VM, and Balskus EP (2017) Chemical transformation of xenobiotics by the human gut microbiota. Science 356:6344.

Krishna DR, and Klotz U (1994) Extrahepatic metabolism of drugs in humans. Clin Pharmacokinet 26:144-160.

Lavrijsen K, van Dyck D, van Houdt J, Hendrickx J, Monbaliu J, Woestenborghs R, Meuldermans W, and Heykants J (1995) Reduction of the prodrug loperamide oxide to its 
active drug loperamide in the gut of rats, dogs, and humans. Drug Metab Dispos Biol Fate Chem 23:354-362.

LeBlanc JG, Milani C, de Giori GS, Sesma F, van Sinderen D, and Ventura M (2013) Bacteria as vitamin suppliers to their host: a gut microbiota perspective. Curr Opin Biotechnol 24:160-168.

Lee HJ, Zhang H, Orlovich DA, and Fawcett JP (2012) The influence of probiotic treatment on sulfasalazine metabolism in rat. Xenobiotica Fate Foreign Compd Biol Syst 42:791-797.

Lee SH, Choi N, and Sung JH (2019) Pharmacokinetic and pharmacodynamic insights from microfluidic intestine-on-a-chip models. Expert Opin Drug Metab Toxicol 15:1005-1019.

Li C, Ai G, Wang Y, Lu Q, Luo C, Tan L, Lin G, Liu Y, Li Y, Zeng H, Chen J, Lin Z, Xian Y, Huang X, Xie J, and Su Z (2020) Oxyberberine, a novel gut microbiota-mediated metabolite of berberine, possesses superior anti-colitis effect: Impact on intestinal

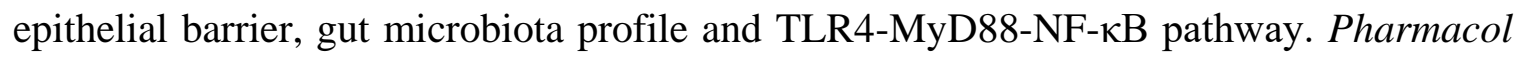
Res 152:104603.

Lindenbaum J., Rund DG, Butler VP, Tse-Eng D, and Saha JR (1981) Inactivation of digoxin by the gut flora: reversal by antibiotic therapy. N Engl J Med 305:789-794.

Lindenbaum John, Tse-Eng D, Butler VP, and Rund DG (1981) Urinary excretion of reduced metabolites of digoxin. Am J Med 71:67-74. 
LoGuidice A, Wallace BD, Bendel L, Redinbo MR, and Boelsterli UA (2012) Pharmacologic targeting of bacterial $\beta$-glucuronidase alleviates nonsteroidal anti-inflammatory druginduced enteropathy in mice. J Pharmacol Exp Ther 341:447-454.

Lozupone CA, Stombaugh JI, Gordon JI, Jansson JK, and Knight R (2012) Diversity, stability and resilience of the human gut microbiota. Nature 489:220-230.

Lukovac S, Belzer C, Pellis L, Keijser BJ, de Vos WM, Montijn RC, and Roeselers G (2014) Differential Modulation by Akkermansia muciniphila and Faecalibacterium prausnitzii of Host Peripheral Lipid Metabolism and Histone Acetylation in Mouse Gut Organoids. mBio 5:e01438-14.

Macfarlane GT, and Macfarlane LE (2009) Acquisition, evolution and maintenance of the normal gut microbiota. Dig Dis Basel Switz 27 Suppl 1:90-98.

Maier L, Pruteanu M, Kuhn M, Zeller G, Telzerow A, Anderson EE, Brochado AR, Fernandez KC, Dose H, Mori H, Patil KR, Bork P, and Typas A (2018) Extensive impact of nonantibiotic drugs on human gut bacteria. Nature 555:623-628.

Malik MY, Jaiswal S, Sharma A, Shukla M, and Lal J (2016) Role of enterohepatic recirculation in drug disposition: cooperation and complications. Drug Metab Rev 48:281-327.

Mariam RR, Rama S, and Ramy KA (2010) The Human Microbiome Project, Personalized Medicine and the Birth of Pharmacomicrobiomics. Curr Pharmacogenomics Pers Med 8:182-193. 
McCabe M, Sane RS, Keith-Luzzi M, Xu J, King I, Whitcher-Johnstone A, Johnstone N, Tweedie DJ, and Li Y (2015) Defining the Role of Gut Bacteria in the Metabolism of Deleobuvir: In Vitro and In Vivo Studies. Drug Metab Dispos Biol Fate Chem 43:16121618.

Meinl W, Sczesny S, Brigelius-Flohé R, Blaut M, and Glatt H (2009) Impact of gut microbiota on intestinal and hepatic levels of phase 2 xenobiotic-metabolizing enzymes in the rat. Drug Metab Dispos Biol Fate Chem 37:1179-1186.

Metagenomics of the Human Intestinal Tract | METAHIT Project | FP7 | CORDIS | European Commission (accessed 10.04.21).

Min S, Kim S, and Cho S-W (2020) Gastrointestinal tract modeling using organoids engineered with cellular and microbiota niches. Exp Mol Med 52:227-237.

Molinero N, Ruiz L, Sánchez B, Margolles A, and Delgado S (2019) Intestinal Bacteria Interplay With Bile and Cholesterol Metabolism: Implications on Host Physiology. Front Physiol 10, Frontiers.

Molly K, Vande Woestyne M, and Verstraete W (1993) Development of a 5-step multi-chamber reactor as a simulation of the human intestinal microbial ecosystem. Appl Microbiol Biotechnol 39:254-258.

Molly K, Woestyne M, De Smet I, and Verstraete W (2009) Validation of the Simulator of the Human Intestinal Microbial Ecosystem (SHIME) Reactor Using Microorganismassociated Activities. Microb Ecol Health D 7:191-200. 
Movva R, Lobb M, Ó Cuív P, Florin THJ, Duley JA, and Oancea I (2016) Microbial metabolism of thiopurines: A method to measure thioguanine nucleotides. J Microbiol Methods 128:102-107.

Nakayama H, Kinouchi T, Kataoka K, Akimoto S, Matsuda Y, and Ohnishi Y (1997) Intestinal anaerobic bacteria hydrolyze sorivudine, producing the high blood concentration of 5(E)-(2-bromovinyl)uracil that increases the level and toxicity of 5-fluorouracil. Pharmacogenetics 7:35-43.

Narozanska E, Bialecka M, Adamiak-Giera U, Gawronska-Szklarz B, Soltan W, Schinwelski M, Robowski P, Madalinski MH, and Slawek J (2014) Pharmacokinetics of Levodopa in Patients With Parkinson Disease and Motor Fluctuations Depending on the Presence of Helicobacter pylori Infection. Clin Neuropharmacol 37:96-99.

Natividad JMM, and Verdu EF (2013) Modulation of intestinal barrier by intestinal microbiota: pathological and therapeutic implications. Pharmacol Res 69:42-51.

Nguyen TLA, Vieira-Silva S, Liston A, and Raes J (2015) How informative is the mouse for human gut microbiota research? Dis Model Mech 8:1-16.

Niehues M, and Hensel A (2009) In-vitro interaction of L-dopa with bacterial adhesins of Helicobacter pylori: an explanation for clinicial differences in bioavailability? J Pharm Pharmacol 61:1303-1307.

Nuriel-Ohayon M, Neuman H, and Koren O (2016) Microbial Changes during Pregnancy, Birth, and Infancy. Front Microbiol 7:1031. 
Oancea I, Movva R, Das I, Cárcer DA de, Schreiber V, Yang Y, Purdon A, Harrington B, Proctor M, Wang R, Sheng Y, Lobb M, Lourie R, Cuív PÓ, Duley JA, Begun J, and Florin THJ (2017) Colonic microbiota can promote rapid local improvement of murine colitis by thioguanine independently of T lymphocytes and host metabolism. Gut 66:5969.

Okuda H, Ogura K, Kato A, Takubo H, and Watabe T (1998) A possible mechanism of eighteen patient deaths caused by interactions of sorivudine, a new anti-viral drug, with oral 5fluorouracil prodrugs. J Pharmacol Exp Ther 287:791-799.

Payne A, Zihler A, Chassard C, and Lacroix C (2011) Advances and perspectives in in vitro human gut fermentation modeling. Trends Biotechnol 30:17-25.

Peppercorn MA, and Goldman P (1972) The role of intestinal bacteria in the metabolism of salicylazosulfapyridine. J Pharmacol Exp Ther 181:555-562.

Pickard JM, Zeng MY, Caruso R, and Núñez G (2017) Gut Microbiota: Role in Pathogen Colonization, Immune Responses and Inflammatory Disease. Immunol Rev 279:70-89.

Pierantozzi M, Pietroiusti A, Galante A, Sancesario G, Lunardi G, Fedele E, Giacomini P, and Stanzione P (2001) Helicobacter pylori-induced reduction of acute levodopa absorption in Parkinson's disease patients. Ann Neurol 50:686-687.

Poewe W, Seppi K, Tanner CM, Halliday GM, Brundin P, Volkmann J, Schrag A-E, and Lang AE (2017) Parkinson disease. Nat Rev Dis Primer 3:17013. 
Possamai LA, McPhail MJ, Khamri W, Wu B, Concas D, Harrison M, Williams R, Cox RD, Cox IJ, Anstee QM, and Thursz MR (2015) The role of intestinal microbiota in murine models of acetaminophen-induced hepatotoxicity. Liver Int Off J Int Assoc Study Liver 35:764773.

Rafii F, Sutherland JB, Hansen EB, and Cerniglia CE (1997) Reduction of nitrazepam by Clostridium leptum, a nitroreductase-producing bacterium isolated from the human intestinal tract. Clin Infect Dis Off Publ Infect Dis Soc Am 25 Suppl 2:S121-122.

Rautava S, Luoto R, Salminen S, and Isolauri E (2012) Microbial contact during pregnancy, intestinal colonization and human disease. Nat Rev Gastroenterol Hepatol 9:565-576.

"Environmental Chemicals, the Human Microbiome, and Health Risk: A Research Strategy" Washington (DC): National Academies Press (US); 2017 Dec 29. The National Academies Collection: Reports funded by National Institutes of Health.

Ritter P of CPGK and STMSJM, Flower RJ, Henderson G, Loke YK, MacEwan D, and Rang HP (2018) Rang \& Dale’s Pharmacology E-Book, Elsevier Health Sciences.

Rodríguez JM, Murphy K, Stanton C, Ross RP, Kober OI, Juge N, Avershina E, Rudi K, Narbad A, Jenmalm MC, Marchesi JR, and Collado MC (2015) The composition of the gut microbiota throughout life, with an emphasis on early life. Microb Ecol Health Dis 26(1):26050.

Routy B, Gopalakrishnan V, Daillère R, Zitvogel L, Wargo JA, and Kroemer G (2018) The gut microbiota influences anti-cancer immunosurveillance and general health. Nat Rev Clin Oncol 15:382-396. 
Routy B, Le Chatelier E, Derosa L, Duong CPM, Alou MT, Daillère R, Fluckiger A, Messaoudene M, Rauber C, Roberti MP, Fidelle M, Flament C, Poirier-Colame V, Opolon P, Klein C, Iribarren K, Mondragón L, Jacquelot N, Qu B, Ferrere G, Clémenson C, Mezquita L, Masip JR, Naltet C, Brosseau S, Kaderbhai C, Richard C, Rizvi H, Levenez F, Galleron N, Quinquis B, Pons N, Ryffel B, Minard-Colin V, Gonin P, Soria JC, Deutsch E, Loriot Y, Ghiringhelli F, Zalcman G, Goldwasser F, Escudier B, Hellmann MD, Eggermont A, Raoult D, Albiges L, Kroemer G, and Zitvogel L (2018) Gut microbiome influences efficacy of PD-1-based immunotherapy against epithelial tumors. Science 359:91-97.

Saha JR, Butler VP, Neu HC, and Lindenbaum J (1983) Digoxin-inactivating bacteria: identification in human gut flora. Science 220:325-327.

Saitta KS, Zhang C, Lee KK, Fujimoto K, Redinbo MR, and Boelsterli UA (2014) Bacterial $\beta$ glucuronidase inhibition protects mice against enteropathy induced by indomethacin, ketoprofen or diclofenac: mode of action and pharmacokinetics. Xenobiotica Fate Foreign Compd Biol Syst 44:28-35.

Sandler M, Karoum F, Ruthven CR, and Calne DB (1969) m-Hydroxyphenylacetic acid formation from L-dopa in man: suppression by neomycin. Science 166:1417-1418.

Sanschagrin S, and Yergeau E (2014) Next-generation Sequencing of 16S Ribosomal RNA Gene Amplicons. J Vis Exp JoVE 90: e51709.

Scott TA, Quintaneiro LM, Norvaisas P, Lui PP, Wilson MP, Leung K-Y, Herrera-Dominguez L, Sudiwala S, Pessia A, Clayton PT, Bryson K, Velagapudi V, Mills PB, Typas A, 
Greene NDE, and Cabreiro F (2017) Host-Microbe Co-metabolism Dictates Cancer Drug Efficacy in C. elegans. Cell 169:442-456.e18.

Selwyn FP, Cheng SL, Klaassen CD, and Cui JY (2016) Regulation of Hepatic DrugMetabolizing Enzymes in Germ-Free Mice by Conventionalization and Probiotics. Drug Metab Dispos Biol Fate Chem 44:262-274.

Sender R, Fuchs S, and Milo R (2016) Revised Estimates for the Number of Human and Bacteria Cells in the Body. PLoS Biol 14:e1002533.

Shah P, Fritz JV, Glaab E, Desai MS, Greenhalgh K, Frachet A, Niegowska M, Estes M, Jäger C, Seguin-Devaux C, Zenhausern F, and Wilmes P (2016) A microfluidics-based in vitro model of the gastrointestinal human-microbe interface. Nat Commun 7:11535.

Sharma A, Buschmann MM, and Gilbert JA (2019) Pharmacomicrobiomics: The Holy Grail to Variability in Drug Response? Clin Pharmacol Ther 106:317-328.

Shu YZ, Kingston DG, Van Tassell RL, and Wilkins TD (1991) Metabolism of levamisole, an anti-colon cancer drug, by human intestinal bacteria. Xenobiotica Fate Foreign Compd Biol Syst 21:737-750.

Sivan A, Corrales L, Hubert N, Williams JB, Aquino-Michaels K, Earley ZM, Benyamin FW, Lei YM, Jabri B, Alegre M-L, Chang EB, and Gajewski TF (2015) Commensal Bifidobacterium promotes antitumor immunity and facilitates anti-PD-L1 efficacy. Science 350(6264):1084-1089. 
Sousa T, Paterson R, Moore V, Carlsson A, Abrahamsson B, and Basit AW (2008) The gastrointestinal microbiota as a site for the biotransformation of drugs. Int J Pharm 363:1-25.

Strong HA, Renwick AG, George CF, Liu YF, and Hill MJ (1987) The reduction of sulphinpyrazone and sulindac by intestinal bacteria. Xenobiotica Fate Foreign Compd Biol Syst 17:685-696.

Sun C, Chen L, and Shen Z (2019) Mechanisms of gastrointestinal microflora on drug metabolism in clinical practice. Saudi Pharm J SPJ 27:1146-1156.

Taguer M, and Maurice CF (2016) The complex interplay of diet, xenobiotics, and microbial metabolism in the gut: Implications for clinical outcomes. Clin Pharmacol Ther 99:588599.

Takasuna K, Hagiwara T, Hirohashi M, Kato M, Nomura M, Nagai E, Yokoi T, and Kamataki T (1996) Involvement of beta-glucuronidase in intestinal microflora in the intestinal toxicity of the antitumor camptothecin derivative irinotecan hydrochloride (CPT-11) in rats. Cancer Res 56:3752-3757.

Takeno S, and Sakai T (1991) Involvement of the intestinal microflora in nitrazepam-induced teratogenicity in rats and its relationship to nitroreduction. Teratology 44:209-214.

Tamura G, Gold C, Ferro-Luzzi A, and Ames BN (1980) Fecalase: a model for activation of dietary glycosides to mutagens by intestinal flora. Proc Natl Acad Sci U S A 77:49614965. 
Tanaka Y, Yamato M, Okano T, Kitamori T, and Sato K (2006) Evaluation of effects of shear stress on hepatocytes by a microchip-based system. Meas Sci Technol 17:3167-3170.

Tang W, and Lu AYH (2010) Metabolic bioactivation and drug-related adverse effects: current status and future directions from a pharmaceutical research perspective. Drug Metab Rev 42:225-249.

Turnbaugh PJ, Ley RE, Hamady M, Fraser-Liggett CM, Knight R, and Gordon JI (2007) The Human Microbiome Project. Nature 449:804-810.

Ursell LK, and Knight R (2013) Xenobiotics and the human gut microbiome: metatranscriptomics reveal the active players. Cell Metab 17:317-318.

Van den Abbeele P, Roos S, Eeckhaut V, MacKenzie DA, Derde M, Verstraete W, Marzorati M, Possemiers S, Vanhoecke B, Van Immerseel F, and Van de Wiele T (2012) Incorporating a mucosal environment in a dynamic gut model results in a more representative colonization by lactobacilli. Microb Biotechnol 5:106-115.

Vermes A, Kuijper EJ, Guchelaar H-J, and Dankert J (2003) An in vitro study on the active conversion of flucytosine to fluorouracil by microorganisms in the human intestinal microflora. Chemotherapy 49:17-23.

Viaud S, Flament C, Zoubir M, Pautier P, LeCesne A, Ribrag V, Soria J-C, Marty V, Vielh P, Robert C, Chaput N, and Zitvogel L (2011) Cyclophosphamide induces differentiation of Th17 cells in cancer patients. Cancer Res 71:661-665. 
Viaud S, Saccheri F, Mignot G, Yamazaki T, Daillère R, Hannani D, Enot DP, Pfirschke C, Engblom C, Pittet MJ, Schlitzer A, Ginhoux F, Apetoh L, Chachaty E, Woerther P-L, Eberl G, Bérard M, Ecobichon C, Clermont D, Bizet C, Gaboriau-Routhiau V, CerfBensussan N, Opolon P, Yessaad N, Vivier E, Ryffel B, Elson CO, Doré J, Kroemer G, Lepage P, Boneca IG, Ghiringhelli F, and Zitvogel L (2013) The intestinal microbiota modulates the anticancer immune effects of cyclophosphamide. Science 342:971-976.

Vickerman V, Blundo J, Chung S, and Kamm R (2008) Design, fabrication and implementation of a novel multi-parameter control microfluidic platform for three-dimensional cell culture and real-time imaging. Lab Chip 8:1468-1477.

Wallace BD, Wang H, Lane KT, Scott JE, Orans J, Koo JS, Venkatesh M, Jobin C, Yeh L-A, Mani S, and Redinbo MR (2010) Alleviating cancer drug toxicity by inhibiting a bacterial enzyme. Science 330:831-835.

Weersma RK, Zhernakova $\mathrm{A}$, and $\mathrm{Fu}$ J (2020) Interaction between drugs and the gut microbiome. Gut 69:1510-1519.

Wilkinson EM, Ilhan ZE, and Herbst-Kralovetz MM (2018) Microbiota-drug interactions: Impact on metabolism and efficacy of therapeutics. Maturitas 112:53-63.

Wos-Oxley ML, Bleich A, Oxley APA, Kahl S, Janus LM, Smoczek A, Nahrstedt H, Pils MC, Taudien S, Platzer M, Hedrich H-J, Medina E, and Pieper DH (2012) Comparative evaluation of establishing a human gut microbial community within rodent models. Gut Microbes 3:234-249. 
Wu B (2012) Use of physiologically based pharmacokinetic models to evaluate the impact of intestinal glucuronide hydrolysis on the pharmacokinetics of aglycone. J Pharm Sci 101:1281-1301.

Wu H, Esteve E, Tremaroli V, Khan MT, Caesar R, Mannerås-Holm L, Ståhlman M, Olsson LM, Serino M, Planas-Fèlix M, Xifra G, Mercader JM, Torrents D, Burcelin R, Ricart W, Perkins R, Fernàndez-Real JM, and Bäckhed F (2017) Metformin alters the gut microbiome of individuals with treatment-naive type 2 diabetes, contributing to the therapeutic effects of the drug. Nat Med 23:850-858.

Xiong W, Abraham PE, Li Z, Pan C, and Hettich RL (2015) Microbial metaproteomics for characterizing the range of metabolic functions and activities of human gut microbiota. Proteomics 15:3424-3438.

Yan A, Culp E, Perry J, Lau JT, MacNeil LT, Surette MG, and Wright GD (2018) Transformation of the Anticancer Drug Doxorubicin in the Human Gut Microbiome. ACS Infect Dis 4:68-76.

Yeo HK, Hyun Y-J, Jang S-E, Han MJ, Lee YS, and Kim D-H (2012) Development of fecal microbial enzyme mix for mutagenicity assay of natural products. J Microbiol Biotechnol 22:838-848.

Yip LY, and Chan ECY (2015) Investigation of Host-Gut Microbiota Modulation of Therapeutic Outcome. Drug Metab Dispos Biol Fate Chem 43:1619-1631. 
Yoo D-H, Kim IS, Van Le TK, Jung I-H, Yoo HH, and Kim D-H (2014) Gut microbiotamediated drug interactions between lovastatin and antibiotics. Drug Metab Dispos Biol Fate Chem 42:1508-1513.

Yoo HH, Kim IS, Yoo D-H, and Kim D-H (2016) Effects of orally administered antibiotics on the bioavailability of amlodipine: gut microbiota-mediated drug interaction. $J$ Hypertens 34:156-162.

Zd F, Fp S, Jy C, and Cd K (2016) RNA Sequencing Quantification of Xenobiotic-Processing Genes in Various Sections of the Intestine in Comparison to the Liver of Male Mice. Drug Metab Dispos Biol Fate Chem 44(6):842-856.

Zhu Y, Zhou J-M, Liu W, Pi X, Zhou Q, Li P, Zhou T, and Gu Q (2021) Effects of exopolysaccharide from Lactobacillus rhamnosus on human gut microbiota in in vitro fermentation model. LWT 139:110524.

Zhuang X, and Lu C (2016) PBPK modeling and simulation in drug research and development. Acta Pharm Sin B 6:430-440.

Zimmermann M, Zimmermann-Kogadeeva M, Wegmann R, and Goodman AL (2019a) Mapping human microbiome drug metabolism by gut bacteria and their genes. Nature 570:462467.

Zimmermann M, Zimmermann-Kogadeeva M, Wegmann R, and Goodman AL (2019b) Separating host and microbiome contributions to drug pharmacokinetics and toxicity. Science 363:6427. 
Zou L, Spanogiannopoulos P, Pieper LM, Chien H-C, Cai W, Khuri N, Pottel J, Vora B, Ni Z, Tsakalozou E, Zhang W, Shoichet BK, Giacomini KM, and Turnbaugh PJ (2020) Bacterial metabolism rescues the inhibition of intestinal drug absorption by food and drug additives. Proc Natl Acad Sci U S A 117:16009-16018. 
Footnotes: This work received no external funding 


\section{Figure legends}

Figure 1: The gut microbiota can perform metabolism of drugs by different modes of action: a) activation of drug which includes conversion of prodrug to its active form, b) deactivation of drug which results in loss in therapeutic efficacy of drug by inactivating it, c) conversion of drug to a toxic metabolite leading to an adverse drug reaction, d) reactivation of drug through enterohepatic recycling, e) direct binding of drug to microbial cells due to adhesive proteins on the microbial cell surface, f) competitive binding of microbial metabolite with the drug for host enzyme, g) modification of the host gene expression and altered expression of crucial genes necessary for drug metabolism, h) immunomodulation or translocation of microbes that stimulates differentiation of immune cells and develop autoimmunity.

Figure 2: Reactivation of drug by gut microbiota induced enterohepatic cycling. Enterohepatic recycling includes two processes- i) biliary excretion followed by ii) intestinal absorption of drug or its metabolite. In the former part, drugs and metabolites which are formed due to action of liver enzymes are the inactivated or conjugated form of the drug and are secreted and concentrated in the bile; in the later part the drug or the metabolites are released from the gall bladder and drained into the intestine where the action of microbial enzymes converts the inactivated or conjugated for of drugs to its active or deconjugated form. This activated or deconjugated form of drug can be absorbed through the hepatic portal vein and get back into systemic circulation.

Figure 3: Different experimental approaches to analyze the metabolism of drugs by gut microbiota 
DMD Fast Forward. Published on December 30, 2021 as DOI: 10.1124/dmd.121.000669

This article has not been copyedited and formatted. The final version may differ from this version. 
Table 1: Biotransformation reactions performed by gut microbiota

\begin{tabular}{|c|c|c|c|c|c|c|}
\hline $\begin{array}{l}\text { Type of } \\
\text { reaction }\end{array}$ & $\begin{array}{c}\text { Drug } \\
\text { exemplar }\end{array}$ & $\begin{array}{c}\text { Class of } \\
\text { drug }\end{array}$ & $\begin{array}{c}\text { Produced drug } \\
\text { metabolites }\end{array}$ & Outcome & 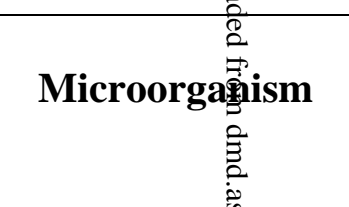 & Reference \\
\hline $\begin{array}{l}\text { Azo-bond } \\
\text { reduction }\end{array}$ & Sulfasalazine & $\begin{array}{l}\text { Anti- } \\
\text { inflammatory }\end{array}$ & $\begin{array}{l}\text { 5-Aminosalicylic } \\
\text { acid and } \\
\text { sulphapyridine }\end{array}$ & $\begin{array}{l}\text { Activation of } \\
\text { prodrug }\end{array}$ & 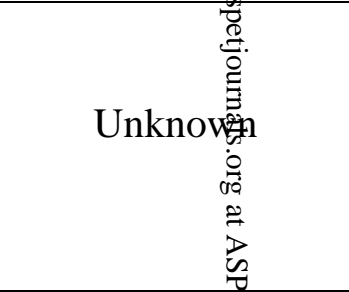 & $\begin{array}{l}\text { (Peppercorn } \\
\text { and Goldman, } \\
\text { 1972) }\end{array}$ \\
\hline $\begin{array}{l}\text { Alkene double } \\
\text { bond reduction }\end{array}$ & Digoxin & $\begin{array}{l}\text { Cardiac } \\
\text { glycoside }\end{array}$ & Dihydrodigoxin & $\begin{array}{l}\text { Reduction of } \\
\text { therapeutic efficacy }\end{array}$ & Eggerthela毒enta & $\begin{array}{c}\text { (J. } \\
\text { Lindenbaum } \\
\text { et al., 1981) }\end{array}$ \\
\hline $\begin{array}{l}\text { Carbonyl } \\
\text { double bond } \\
\text { reduction }\end{array}$ & Tacrolimus & $\begin{array}{l}\text { Immuno- } \\
\text { suppressant }\end{array}$ & $\begin{array}{c}\text { 9- } \\
\text { Hydroxytacrolimus }\end{array}$ & $\begin{array}{l}\text { Low and variable } \\
\text { exposure to the } \\
\text { immunosuppressan } \\
\text { t }\end{array}$ & $\begin{array}{c}\stackrel{\circ}{\tilde{N}} \\
\stackrel{\omega}{\omega} \\
\text { Faecalibacteriump } \\
\text { rausnitzii }\end{array}$ & $\begin{array}{l}\text { (Guo et al., } \\
\text { 2019) }\end{array}$ \\
\hline Nitro reduction & Nitrazepam & Hypnotic & 7-Aminonitrazepam & $\begin{array}{c}\text { Produces 7- } \\
\text { acetylaminonitraze } \\
\text { pam having }\end{array}$ & Clostridium leptum & $\begin{array}{c}\text { (Rafii et al., } \\
\text { 1997) }\end{array}$ \\
\hline
\end{tabular}




\begin{tabular}{|c|c|c|c|c|c|c|}
\hline & & & & $\begin{array}{l}\text { teratogenic } \\
\text { potential }\end{array}$ & 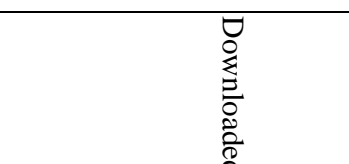 & \\
\hline $\begin{array}{l}\mathrm{N} \text {-oxide } \\
\text { reduction }\end{array}$ & $\begin{array}{c}\text { Loperamide } \\
\text { oxide }\end{array}$ & $\begin{array}{c}\text { Anti- } \\
\text { diarrheal }\end{array}$ & Loperamide & $\begin{array}{l}\text { Activation of } \\
\text { prodrug }\end{array}$ & 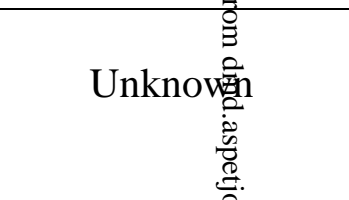 & $\begin{array}{c}\text { (Lavrijsen et } \\
\text { al., 1995) }\end{array}$ \\
\hline $\begin{array}{l}\text { Sulfoxide } \\
\text { reduction }\end{array}$ & Sulindac & NSAID & Sulindac sulfide & $\begin{array}{l}\text { Activation of } \\
\text { prodrug }\end{array}$ & 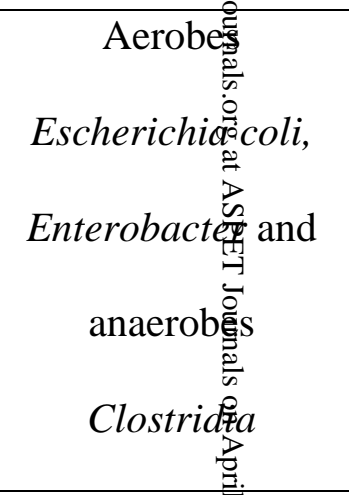 & $\begin{array}{c}\text { (Strong et al., } \\
\text { 1987) }\end{array}$ \\
\hline Hydrolysis & Sorivudine & Anti-viral & $\begin{array}{l}\text { (E)-5-(2- } \\
\text { bromovinyl) uracil }\end{array}$ & $\begin{array}{l}\text { Lethal effects due } \\
\text { to combination of } \\
\text { Sorivudine and 5- } \\
\text { fluorouracil }\end{array}$ & 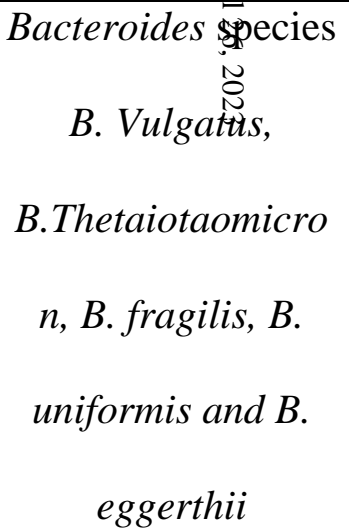 & $\begin{array}{c}\text { (Nakayama et } \\
\text { al., 1997; } \\
\text { Okuda et al., } \\
\text { 1998) }\end{array}$ \\
\hline Proteolysis & Calcitonin & Synthetic & Unknown & Degradation of & Unknown & (Sousa et al., \\
\hline
\end{tabular}




\begin{tabular}{|c|c|c|c|c|c|c|}
\hline & & hormone & & $\begin{array}{l}\text { peptide drug } \\
\text { causing loss of } \\
\text { therapeutic efficacy }\end{array}$ & 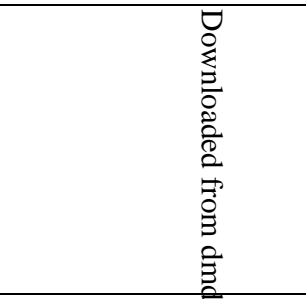 & 2008) \\
\hline $\begin{array}{c}\text { De- } \\
\text { conjugation }\end{array}$ & $\begin{array}{l}\text { Irinotecan } \\
\text { metabolite }\end{array}$ & Anti-cancer & SN-38 & Intestinal toxicity & 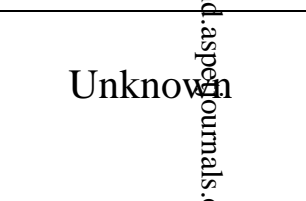 & $\begin{array}{c}\text { (Takasuna et } \\
\text { al., 1996) }\end{array}$ \\
\hline $\begin{array}{l}\text { De- } \\
\text { hydroxylation }\end{array}$ & Levodopa & $\begin{array}{l}\text { Anti- } \\
\text { parkinsonian }\end{array}$ & $\begin{array}{l}\text { m-Tyramine and m- } \\
\text { hydroxyphenyl } \\
\text { acetic acid }\end{array}$ & $\begin{array}{l}\text { Reduced } \\
\text { therapeutic activity }\end{array}$ & 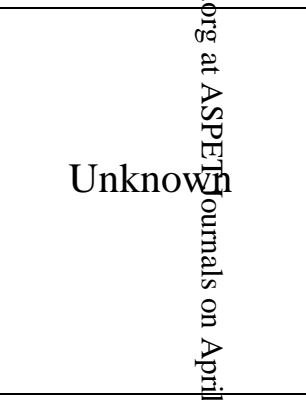 & $\begin{array}{c}\text { (Sandler et } \\
\text { al., 1969; } \\
\text { Goldin et al., } \\
\text { 1973) }\end{array}$ \\
\hline $\begin{array}{l}\text { De- } \\
\text { methylation }\end{array}$ & Imipramine & $\begin{array}{l}\text { Tricyclic } \\
\text { anti- } \\
\text { depressant }\end{array}$ & Desipramine & $\begin{array}{l}\text { Conversion to } \\
\text { active metabolite } \\
\text { causing variation in } \\
\text { response to } \\
\text { imipramine therapy }\end{array}$ & $\begin{array}{c}\text { Aerobeg } \\
\text { Escherichiōं } \\
\text { Klebsiella } \\
\text { pneumoniae and } \\
\text { anaerobes } \\
\text { Fusobacterium } \\
\text { fusiforme }\end{array}$ & $\begin{array}{c}\text { (Clark et al., } \\
\text { 1983) }\end{array}$ \\
\hline
\end{tabular}




\begin{tabular}{|c|c|c|c|c|c|c|}
\hline Acetylation & $\begin{array}{l}\text { 5- } \\
\text { Aminosalicyl } \\
\text { ic acid }\end{array}$ & $\begin{array}{l}\text { Metabolite of } \\
\text { sulfasalazine }\end{array}$ & $\begin{array}{l}\text { N-Acetyl-5- } \\
\text { aminosalicylic acid }\end{array}$ & $\begin{array}{l}\text { Therapeutic } \\
\text { inactivation of the } \\
\text { drug }\end{array}$ & 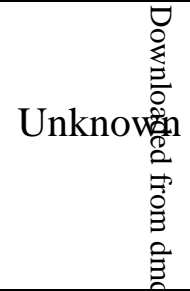 & $\begin{array}{l}\text { (Allgayer } e t \\
\text { al., 1989) }\end{array}$ \\
\hline De-acetylation & Aspirin & $\begin{array}{l}\text { NSAID and } \\
\text { anti- } \\
\text { thrombotic }\end{array}$ & $\begin{array}{l}\text { Salicylic acid and } \\
\text { hydroxylated } \\
\text { salicylic acid }\end{array}$ & $\begin{array}{l}\text { Decrease in anti- } \\
\text { thrombotic effect } \\
\text { of the drug }\end{array}$ & 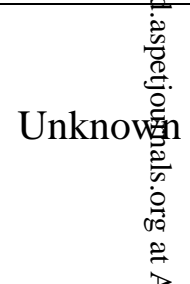 & $\begin{array}{l}\text { (IS Kim et al., } \\
\text { 2016) }\end{array}$ \\
\hline De-amination & $\begin{array}{l}\text { 5- } \\
\text { Fluorocytosin } \\
\text { e }\end{array}$ & Anti-fungal & 5-Fluorouracil & $\begin{array}{l}\text { Possible cause of } \\
\text { toxicity of the drug }\end{array}$ & 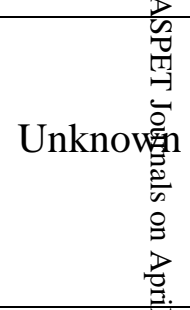 & $\begin{array}{c}\text { (Harris et al., } \\
\text { 1986) }\end{array}$ \\
\hline Oxidation & Lovastatin & $\begin{array}{l}\text { HMG-CoA } \\
\text { reductase } \\
\text { inhibitor }\end{array}$ & $\begin{array}{l}\text { Hydroxylated and } \\
\text { hydroxy acid } \\
\text { metabolites }\end{array}$ & $\begin{array}{l}\text { Inter-individual } \\
\text { variability in } \\
\text { pharmacokinetics }\end{array}$ & $\begin{array}{r}\frac{N}{2} \\
\text { Non } \\
\text { Unknowin }\end{array}$ & $\begin{array}{l}\text { (Yoo et al., } \\
\text { 2014) }\end{array}$ \\
\hline De-nitration & $\begin{array}{l}\text { Glyceryl } \\
\text { trinitrate }\end{array}$ & Anti-anginal & $\begin{array}{l}\text { Glyceryl-1,3- } \\
\text { dinitrate, glyceryl- } \\
\text { 1,2-dinitrate, } \\
\text { glyceryl-1- }\end{array}$ & $\begin{array}{l}\text { Decrease in the } \\
\text { therapeutic activity } \\
\text { of the drug }\end{array}$ & Unknown & $\begin{array}{c}\text { (Sousa et al., } \\
\text { 2008) }\end{array}$ \\
\hline
\end{tabular}




\begin{tabular}{|c|c|c|c|c|c|}
\hline & 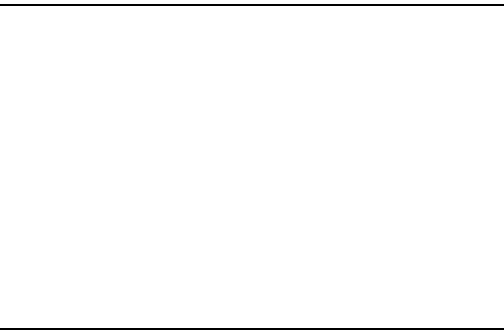 & $\begin{array}{l}\text { mononitrate, } \\
\text { glyceryl-2- } \\
\text { mononitrate }\end{array}$ & & 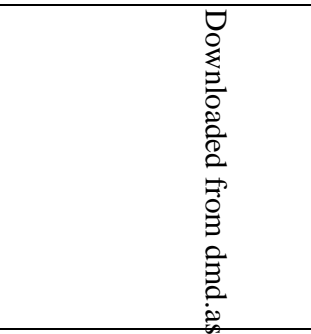 & \\
\hline $\begin{array}{c}\text { Thiazole ring } \\
\text { opening }\end{array}$ & Levamisole Anthelmintic & $\begin{array}{l}\text { Levametabol I, II } \\
\text { and III }\end{array}$ & $\begin{array}{l}\text { The activity of } \\
\text { metabolites not } \\
\text { reported }\end{array}$ & Bacteroidet & $\begin{array}{c}\text { (Shu et al., } \\
\text { 1991) }\end{array}$ \\
\hline & & & & 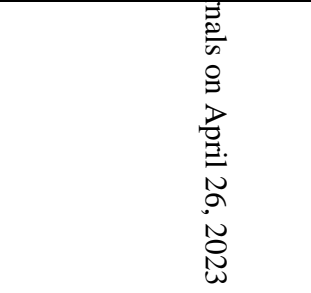 & \\
\hline
\end{tabular}

Table 2: Examples of investigation of drug metabolism by gut microbiota using different approaches

\begin{tabular}{|c|c|c|c|c|c|}
\hline $\begin{array}{l}\text { Sr. } \\
\text { No. }\end{array}$ & Type of study & Drug & $\begin{array}{c}\text { Class of } \\
\text { drug }\end{array}$ & Result & Reference \\
\hline 1 & In vivo murine & Deleobuvir & Hepatitis C & Plasma exposure of reduced metabolite of deleobuvir (CD & (McCabe et al., \\
\hline
\end{tabular}




\begin{tabular}{|c|c|c|c|c|c|}
\hline & model & & & $\begin{array}{c}\text { 6168) was 9-fold lower in pseudo-germ free rats than control } \\
\text { rats }\end{array}$ & 2015) \\
\hline 2 & $\begin{array}{l}\text { In vivo } \\
\text { nematode } \\
\text { model } C \text {. } \\
\text { elegans }\end{array}$ & Doxorubicin & Anti-cancer & $\begin{array}{c}\text { Reduced toxicity of doxorubicin was attributable to } \\
\text { deglycosylation by capsulated bacilli Raoultellaplant } \\
\text { under anaerobic conditions }\end{array}$ & (Yan et al., \\
\hline 3 & In vitro & Flucytosine & Anti-fungal & $\begin{array}{l}\text { Extensive conversion of flucytosine to fluorouracil can } \\
\text { in the human intestinal microflora by } E \text {. coli. Hence } \\
\text { fluorouracil exposure and fluorouracil-related toxicitymay } \\
\text { occur in the flucytosine-treated patient }\end{array}$ & $\begin{array}{l}\text { (Vermes et al., } \\
\text { 2003) }\end{array}$ \\
\hline 4 & Ex vivo & $\begin{array}{l}\text { Epacadostat } \\
\text { (EPA) }\end{array}$ & Anti-cancer & $\begin{array}{l}\text { Amidine metabolite of EPA (M11) and N-dealkylated form of } \\
\text { M11 (M12) were formed in negligible quantities when EPA } \\
\text { was incubated with human microsomes from multiple tissues, } \\
\text { hepatocytes, recombinant human cytochrome P450s. Whereas, } \\
\text { M11 was formed when EPA was incubated with human faecal } \\
\text { homogenates, and the amount of M11 depleted upon addition }\end{array}$ & $\begin{array}{l}\text { (Boer et al., } \\
\text { 2016) }\end{array}$ \\
\hline
\end{tabular}




\begin{tabular}{|c|c|c|c|c|c|}
\hline & & & & 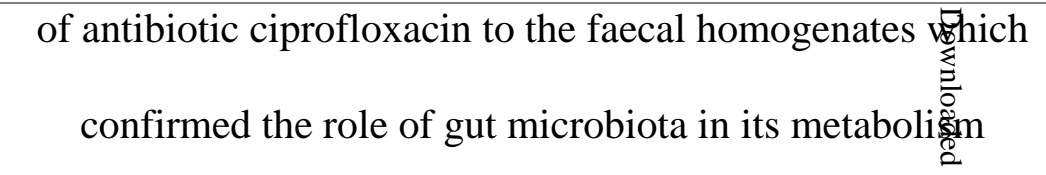 & \\
\hline 5 & In silico & Brivudine & Anti-viral & $\begin{array}{c}\text { PBPK model accurately predicts and separates the hosi and } \\
\text { microbiome mediated metabolism of brivudine to } \\
\text { hepatotoxic metabolite bromovinyluracil }\end{array}$ & $\begin{array}{l}\text { (Zimmermann } \\
\text { et al., 2019b) }\end{array}$ \\
\hline 6 & Multi-omic & Simvastatin & $\begin{array}{l}\text { HMG-CoA } \\
\text { reductase } \\
\text { inhibitor }\end{array}$ & $\begin{array}{l}\text { Metabolomic study revealed that the levels of bacteriatly } \\
\text { derived bile acids assist in predicting the efficacy } \\
\text { simvastatin in lowering LDL cholesterol and raise } \\
\text { possibility of competition } \\
\text { between simvastatin and bile acids for SLCO1B1 transhorter } \\
\text { may influence both the pharmacokinetics and } \\
\text { pharmacodynamics of } \\
\text { simvastatin, and possibly the risk of muscle toxicity }\end{array}$ & $\begin{array}{l}\text { (Kaddurah- } \\
\text { Daouk et al., } \\
\text { 2011) }\end{array}$ \\
\hline
\end{tabular}




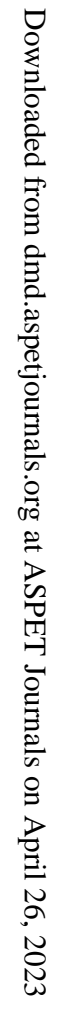




\section{Figure 1}

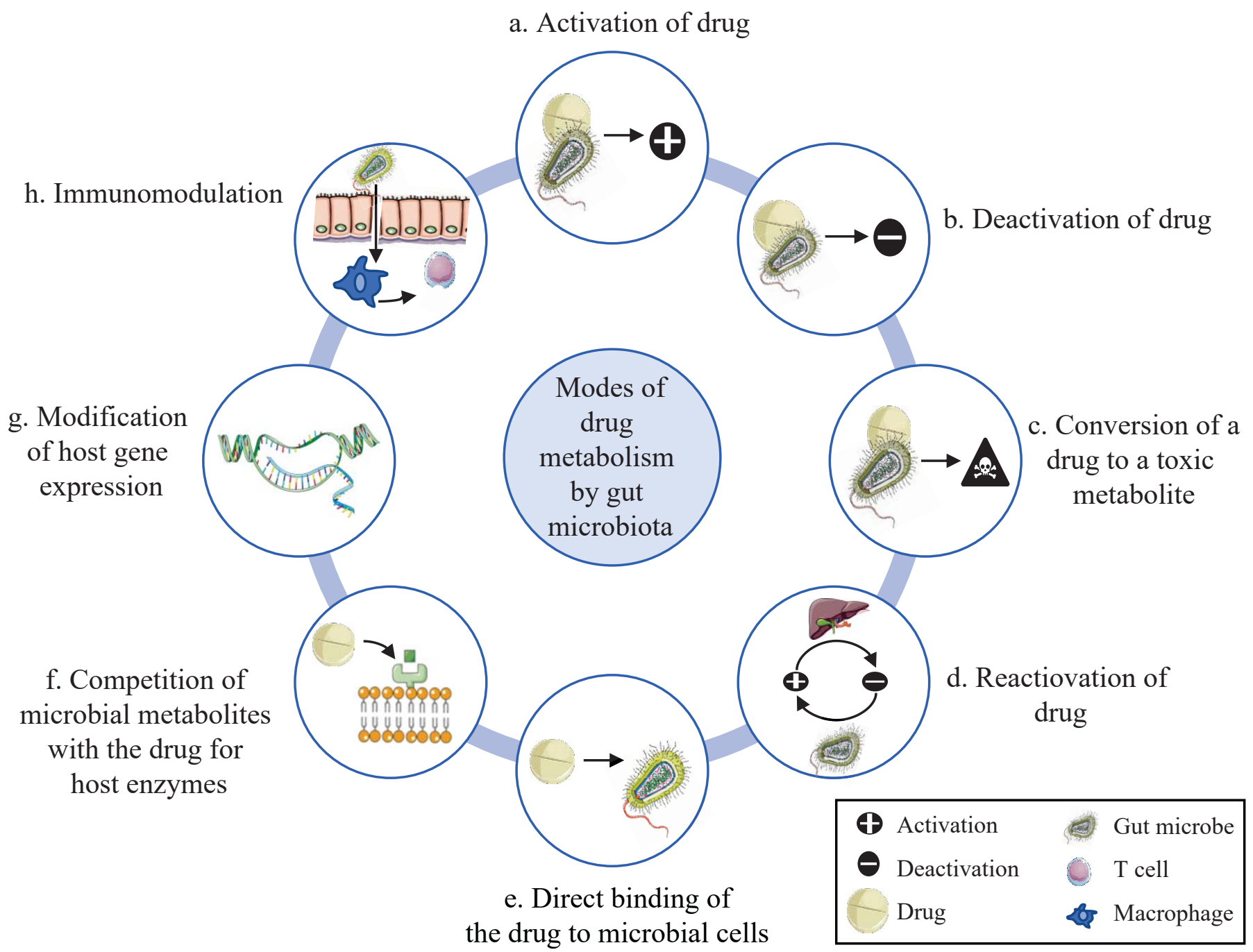


Figure 2

This article has not been copyedited and formatted. The final version may differ from this version.

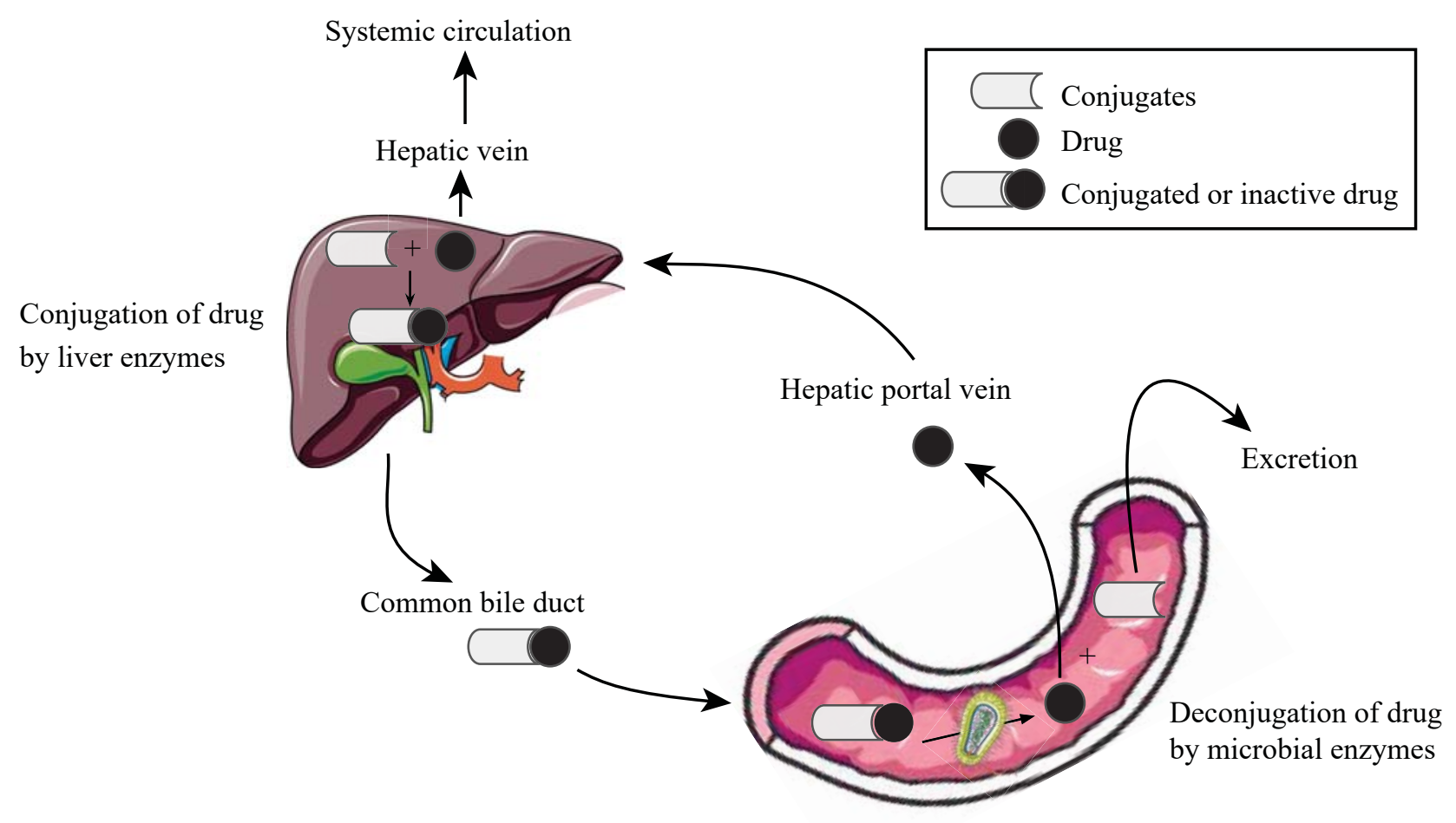


DMD Fast Forward. Published on December 30, 2021 as DOI: 10.1124/dmd.121.000669

This article has not been copyedited and formatted. The final version may differ from this version.

Figure 3

\begin{tabular}{|c|c|c|c|c|}
\hline In vivo & In vitro & Ex vivo & In silico & $\begin{array}{l}\text { Multi-omic } \\
\text { approach }\end{array}$ \\
\hline $\begin{array}{l}\text { C. elegance } \\
\text { model }\end{array}$ & $-\begin{array}{c}2 \mathrm{D} \text { and } 3 \mathrm{D} \text { cell } \\
\text { cultures }\end{array}$ & $-\begin{array}{c}\begin{array}{c}\text { Fecalase and } \\
\text { cecalase activity }\end{array} \\
\text {. }\end{array}$ & $\begin{array}{c}\text { PBPK } \\
\text { modeling }\end{array}$ & $\begin{array}{c}\text { Meta- } \\
\text { genomics }\end{array}$ \\
\hline $\begin{array}{c}\text { Zebra fish } \\
\text { model }\end{array}$ & $\begin{array}{c}\text { Microfluidic } \\
\text { devices }\end{array}$ & $\begin{array}{c}\text { Organoid } \\
\text { cultures }\end{array}$ & & $\begin{array}{c}\text { Meta- } \\
\text { transcriptomics } \\
\end{array}$ \\
\hline Mouse model & $\begin{array}{c}\text { Simulator- } \\
\text { SHIME }\end{array}$ & & & Proteomics \\
\hline & & & & Metabolomics \\
\hline
\end{tabular}

